\author{
Maciej MIŻEJEWSKI \\ Uniwersytet Jagielloński \\ E-mail: presscd@gmail.com
}

\title{
FINANSOWANIE MEDIÓW PUBLICZNYCH W POLITYCE MEDIALNEJ UE
}

\author{
PRZYKŁAD POLSKI, WĘGIER, FRANCJI I NIEMIEC
}

ABSTRACT Financing of public service broadcasting in the EU media policy. Examples of Poland, Hungary, France and Germany

The article analyzes the issue of financing the public media as one of the most complex and controversial part of media policy in the European Union. European institutions have not opted for the specific model of financing, leaving the case to the member states. Using the examples of Poland and Hungary, the author shows how a broadcasting fee can be a bargaining chip for political purposes, and the announcements of the liquidation of such fees in election campaigns can result in further weak position of public broadcasters. In Hungary, receiving further grants and debt relief managed by the government was perceived as "payment for services” to the public broadcaster, rendered in favor of the ruling coalition. On the other hand, indicated examples of France and Germany show how consistently implemented media policy can create stable conditions for the development of public service broadcasters in those countries and provides protection of media pluralism.

KEY WORDS public media, broadcasting, media policy, European Union, financing

Tednym z głównych elementów polityki medialnej Unii Europejskiej jest problem finansowania mediów publicznych ${ }^{1}$. Zagadnienie to budzi polityczne emocje,

A. Woźniak [i in.], Finansowanie mediów audiowizualnych ze środków publicznych - analiza porównawcza na przyktadzie wybranych państw europejskich (aktualizacja), Analiza Biura KRRiT, 2010, nr 3, s. 2-5; Zob.: A. Woźniak [i in.], Systemy poboru optat abonamentowych w wybranych państwach europejskich (aktualizacja), Analiza Biura KRRiT, 2007, nr 5. 
gdyż określenie modelu tego finansowania bezpośrednio wpływa na niezależność publicznej radiofonii i telewizji, ich autonomię redakcyjną oraz poziom komercjalizacji programów. Istotna jest tu zwłaszcza niezależność od świata polityki oraz od presji rynku.

Sprawa ta nabiera szczególnego znaczenia zwłaszcza w dobie konwersji cyfrowej nadawców publicznych, a także stosowania wspólnotowego prawa konkurencji dotyczącego tzw. „pomocy publicznej”'. Poprawa kondycji finansowej nadawców publicznych może być bowiem efektem interwencji państwa, co nie zawsze zgodne jest z realizacją zasady uczciwej konkurencji. W opinii autora określenie modelu finansowania nadawcy publicznego przez dane państwo nie powinno gwarantować mu pozycji dominującej na rynku nadawców.

Autor w niniejszym artykule na przykładzie Polski i Węgier pokazuje, jak abonament może stać się kartą przetargową w rozgrywkach politycznych, a zapowiedź jego zniesienia, traktowana jako jedna z obietnic wyborczych, znacznie osłabić i tak już nie najlepszą kondycję finansową nadawcy publicznego, nie gwarantując mu jednocześnie dostatecznej pomocy finansowej z budżetu państwa, tytułem rekompensaty poniesionych strat. Przykład Węgier najlepiej pokazuje, jak otrzymywanie kolejnych dotacji i umarzanie długów telewizji publicznej przez rząd było odbierane jako „zapłata za usługi", świadczone na rzecz rządzących koalicji.

Z drugiej strony wskazany przez autora przykład Francji i Niemiec dowodzi, jak konsekwentnie realizowana polityka medialna stwarza nadawcom publicznym $\mathrm{w}$ tych krajach stabilne warunki rozwoju w zakresie realizowanych inwestycji oraz poprawy jakości oferty programowej, dzięki zapewnieniu środków publicznych na realizację zadań misyjnych. Jest to możliwe z powodu utrzymania jednego z najwyższych w Europie poziomu wpływów z abonamentu, co gwarantuje wysoki stopień ochrony medialnego pluralizmu. Wpływają na to bez wątpienia, zdaniem autora, najnowsze rozwiązania legislacyjne w niemieckim prawie mediów, dotyczące m.in. systemu poboru abonamentu, które weszły w życie 1 stycznia 2013 r. Przejrzysty mechanizm rozdziału abonamentu i zdecentralizowana struktura organizacyjna nadawców publicznych stanowią najlepszą rękojmię realizacji obywatelskiego prawa do informacji.

Zarówno Unia Europejska, jak i Rada Europy w licznych deklaracjach ${ }^{3}$ wskazywały na konieczność stworzenia nadawcom publicznym stabilnych warunków funkcjonowania, ale żadna z tych organizacji nie opowiedziała się za konkretnym modelem

2 P. Stępka, A. Woźniak, Problem stosowania pomocy publicznej w kontekście dziatalności nadawców publicznych, Analiza Biura KRRiT, 2007, nr 1, s. 8-10.

3 Zob.: Declaration of the Committee of Ministers on the Guarantee of the Independence of Public Service Broadcasting in the Member States (Adopted by the Committee of Ministers on 27 September 2006 at the $974^{\text {th }}$ meeting of the Ministers' Deputies); zob. też: Declaration of the Committee of Ministers on Public Service Media Governance (Adopted by the Committee of Ministers on 15 February 2012 at the $1134^{\text {th }}$ meeting of the Ministers' Deputies); Declaration of the Committee of Ministers on Protecting the Role of the Media in Democracy in the Context of Media Concentration (Adopted by the Committee of Ministers on 31 January 2007at the $985^{\text {th }}$ meeting of the Ministers' Deputies), dostępne on-line: http://www.coe.int/t/dghl/standardsetting/media/Doc/CM_en.asp, 31 I 2013. 
ich finansowania, pozostawiając tę sprawę do rozstrzygnięcia państwom członkowskim. Unia Europejska w protokole amsterdamskim z 1997 r. ${ }^{4}$ usankcjonowała swobodę państw członkowskich w wyborze systemu finansowania radiofonii i telewizji publicznej. Zgodnie z postanowieniami traktatu finansowaniem ze środków publicznych mieli być objęci nadawcy z tytułu realizowania przez nich misji publicznej, zdefiniowanej ustawowo przez poszczególne państwa członkowskie. Przyjęty przez dane państwo model finansowania nadawców publicznych nie powinien naruszać zasad obrotu gospodarczego i konkurencji wewnątrz Wspólnoty.

Zalecenie Rady Europy z 2006 r. ${ }^{5}$ gwarantuje mediom publicznym swobodę w podejmowaniu decyzji finansowych dotyczących ich działalności programowej. Oczekuje ponadto od państw członkowskich stworzenia efektywnego mechanizmu finansowania nadawców publicznych, adekwatnego do ich obowiązków ustawowych w zakresie realizacji misji. Antena nadawców publicznych ma stanowić bowiem forum debaty publicznej i urzeczywistniać w praktyce gwarancje pluralizmu, co realizuje się m.in. poprzez sprzyjanie swobodnemu kształtowaniu się poglądów obywateli.

Komisja Europejska bada to, czy i w jaki sposób został określony w ustawie zakres działań mediów publicznych. Zgodnie z zaleceniem Rady Europy finansowanie nadawców publicznych powinno być długofalowe, tak aby zapewnić mediom stabilne podstawy funkcjonowania i dalszy rozwój w oparciu np. o tworzone strategie inwestycyjne w dobie silnej konkurencji z nadawcami komercyjnymi.

Zalecenie Rady Europy w sposób szczególny akcentuje niezależność nadawców publicznych od wpływów rządowych. Najlepszą gwarancją niezależności jest właśnie zagwarantowanie przez państwo stabilnego źródła finansowania mediom publicznym, np. w formie abonamentu. Wyklucza to chociażby niebezpieczeństwo administracyjnego wpływania na politykę programową nadawców publicznych.

Abonament pomaga stworzyć także bezpośredni związek między społeczeństwem a nadawcą publicznym, którego program jest finansowany bezpośrednio przez obywateli. Istnieją także pośrednie formy finansowania mediów publicznych, jak choćby $n p$. we Francji, gdzie pieniądze z abonamentu wraz z innymi podatkami najpierw trafiają do budżetu państwa, a następnie są rozdzielane poszczególnym nadawcom stosownie do zadań programowych w zakresie realizowanej przez nich misji ${ }^{6}$.

Zgodnie z zaleceniem Rady Europy model finansowania nadawców publicznych powinien w maksymalnym stopniu ograniczać wpływ państwa na media.

Zob.: Protocol on the System of Public Broadcasting in the Member States Annexed to the Treaty of Amsterdam Amending the Treaty on European Union, the Treaties Establishing the European Communities and Certain Related Acts, 1997.

5 Declaration of the Committee of Ministers on the Guarantee of the Independence of Public Service Broadcasting in the Member States (Adopted by the Committee of Ministers on 27 September 2006 at the 974th meeting of the Ministers' Deputies), [online] http://www.coe.int/t/dghl/standardsetting/ media/Doc/CM_en.asp, 31 I 2013.

6 A. Scheuer, Rola $i$ znaczenie mediów publicznych w Europie. Materiaty z konferencji KRRiT, Warszawa 2009, [online] http://www.krrit.gov.pl/Data/Files/_public/Portals/0/konferencje/dm_konf_ 080415_spraw.pdf, 31 I 2013, s. 15. 
Wysokość opłaty abonamentowej może być ustalana przez parlament, choć w opinii autora $\mathrm{w}$ konsekwencji może rodzić to niebezpieczeństwo stworzenia przez państwo skutecznego mechanizmu kontroli, uzależniającego działalność mediów, a zwłaszcza ich politykę programową, od decyzji poszczególnych ugrupowań parlamentarnych.

Powstaje więc podstawowe pytanie: na co powinny być wydawane pieniądze $\mathrm{z}$ abonamentu? Czy realizacja misji przez nadawców publicznych oznacza, że widzowie przestają mieć wpływ na jakość oferty programowej?

Zdaniem autora skuteczną formą kontrolowania wydatków nadawców publicznych jest publikowanie sprawozdań finansowych ze sposobu wydatkowania pieniędzy przeznaczonych na realizację misji. Jeśli widzowie wiedzą, na co i w jaki sposób wydaje się ich pieniądze, łatwiej im jest ponosić koszty finansowania działalności nadawców publicznych oraz akceptować decyzje dotyczące produkcji poszczególnych programów.

Zdaniem Karola Jakubowicza dotychczas, tradycyjnym zadaniem mediów publicznych byto produkowanie programów na antene radiowa lub telewizyjna. Obecnie nie wystarczy mieć pomystu na radio czy telewizje, trzeba mieć też pomyst na nowoczesny sposób komunikowania, zaktadają, że dla potencjalnego odbiorcy będzie to pierwsze źródto informacji o świecie. Oznacza to, że obecnie produkcja programowa powinna być dostosowana do emisji na różnych antenach i nośnikach: w radiu, telewizji, Internecie i w telefonii komórkowej’.

Jest to konsekwencja procesu konwergencji technologicznej, który w równym stopniu dotyczy nadawców publicznych i komercyjnych. Towarzyszy mu proces cyfryzacji, co powoduje, że nadawcy publiczni zmuszeni są do ponownego określenia swojej pozycji na rynku. Rozszerzenie dotychczasowej oferty programowej z zachowaniem standardów dotyczących misji może być konkurencyjne wobec oferty nadawców komercyjnych tylko wtedy, jeśli będzie to konkurowanie jakością i odpowiednio wysokim poziomem warsztatu dziennikarskiego.

Od kiedy pojawiły się media komercyjne, publiczne traciły monopol najpierw na odbiorców, a potem na tzw. treści misyjne. Nadawcy komercyjni otwierali programy wyspecjalizowane, a także zaczęli nadawać wiele programów kojarzonych z tzw. misją ${ }^{8}$.

Zdaniem Jakubowicza sytuacja ta jednak się zmienia: Nadawcy publiczni zaczynaja odzyskiwać swoja pozycje w powszechnie dostępnych programach uniwersalnych, które zawieraja treści ambitne, ponieważ nadawcy komercyjni przenosza bardziej atrakcyjna zawartość do programów specjalistycznych, często ptatnych. Jeżeli ta tendencja będzie

Zob. też: K. Jakubowicz, Unia Europejska a media. Między kultura a gospodarka, Warszawa 2010, Edukacja Medialna; tenże, Polityka medialna a media elektroniczne, Warszawa 2008, Edukacja Medialna.

8 Zob.: tenże, Media publiczne. Początek końca czy nowy początek, Warszawa 2007, Edukacja Medialna; K. Williams, Media w Europie, przeł. A. Piwnicka, Warszawa 2008, Edukacja Medialna. Podręcznik akademicki; Wybrane zagraniczne systemy medialne, red. J.W. Adamowski, Warszawa 2008, Edukacja Medialna; D. Hallin, P. Mancini, Systemy medialne. Trzy modele mediów i polityki w ujęciu porównawczym, przeł. M. Lorek, Kraków 2007, Media. 
się nasilata, to ogólnie dostępna telewizja, zwtaszcza komercyjna, będzie telewizją dla ubogich, a to, co będzie wartościowe, będzie dostępne wytacznie w ptatnych kanatach wyspecjalizowanych'.

To bez wątpienia szansa dla nadawców publicznych, aby utrwalić swą pozycję na rynku i przekonać odbiorców do ambitnej oferty programowej, wysokiej jakości. Nadawcy publiczni zaczynają również odgrywać kluczową rolę w kwestii programów misyjnych, ponieważ nasilenie konkurencji wskutek wzrostu liczby ofert programowych powoduje, że nadawcy komercyjni, walcząc o masowego odbiorcę, coraz rzadziej będą mogli nadawać treści misyjne, zwłaszcza w programach ogólnodostępnych. Przykład Wielkiej Brytanii pokazuje, że w miarę postępu cyfryzacji następuje stopniowa redukcja wymagań misyjnych nakładanych zwłaszcza na nadawców komercyjnych, traktowanych w Anglii jako komercyjni nadawcy publiczni ${ }^{10}$.

Jak wynika z raportów brytyjskiego regulatora OFCOM, wymagania te trzeba będzie redukować, ponieważ w dobie narastającej konkurencji brytyjscy nadawcy komercyjni nie będą w stanie wywiązywać się ze swoich obowiązków misyjnych. Wzrost konkurencji spowodował bowiem przesuwanie wartościowych pozycji do programów wyspecjalizowanych, często płatnych, czego konsekwencją stało się obniżenie jakości programu w kanałach ogólnodostępnych.

Pozycja nadawcy publicznego nie jest więc zagrożona, przeciwnie. Tradycyjna oferta programowa musi jednak zostać wzbogacona o programy wyspecjalizowane, a także dostępne w Internecie, określane mianem spersonalizowanej ustugi publicznej. Efektem rewolucji technologicznej jest bowiem zmiana dotychczasowego modelu nadawcy publicznego, który cechowały powszechność dostępu i emisja treści uniwersalnych, adresowanych do szerokiego grona audytorium.

Nadawca publiczny przez wiele lat korzystał bowiem z pozycji monopolistycznej, emitując program w skali ogólnokrajowej w kilku kanałach, co w początkowym okresie rywalizacji o widza z nadawcami komercyjnymi w pełni wystarczało, tym bardziej że nadawcy komercyjni oferowali widowni głównie programy zapewniające wysokie dochody nadawcy ${ }^{11}$.

Dzisiaj, kiedy liczba ofert programowych rośnie, kiedy pojawia się możliwość personalizacji, ten tradycyjny model nadawcy publicznego, służącego jednocześnie wszystkim, musi ulec zmianie. Media publiczne nie stracą swojego znaczenia, pod warunkiem, że staną się medium interaktywnym, stwarzającym odbiorcom nowe możliwości. Korzystanie przez nadawców publicznych w procesie komunikowania z Internetu,

$9 \quad$ K. Jakubowicz, Rola i znaczenie mediów publicznych w Europie. Materiaty $z$ konferencji KRRiT, Warszawa 2009, [online] http://www.krrit.gov.pl/Data/Files/_public/Portals/0/konferencje/dm_ konf_080415_spraw.pdf, 31 I 2013.

10 Zob.: J.W. Adamowski, Czwarty stan. Media masowe w pejzażu spotecznym Wielkiej Brytanii, Warszawa 2006, s. 277-285; tenże, System medialny Wielkiej Brytanii, [w:] Wybrane zagraniczne systemy medialne, s. 45-86; tenże, Narodziny czwartej wtadzy. Geneza i rozwój brytyjskiego systemu medialnego (zarys problematyki), Warszawa 2005; The Office Of Communications Annual Report and Accounts for the Period 1 April 2010 To 31 March 2011, s. 5-10, [online] http://www.ofcom.org.uk, 31 I 2013.

11 K. Jakubowicz, Polityka medialna..., s. 160 i nast. 
platform mobilnych czy innych nośników programów musi odbywać się na zasadzie komplementarnej, adekwatnie do oczekiwań audytorium ${ }^{12}$.

Dotychczas media publiczne były definiowane za pomocą parametrów technicznych, co znaczyło, że każdy słuchacz radia czy telewidz musiał płacić abonament radiowo-telewizyjny. W opinii Karola Jakubowicza należy odejść od kryterium, jakim jest posiadanie odbiornika radiowego czy telewizyjnego. Obecnie nie ma ono sensu, ponieważ odbiór odbywa się również przez telefony komórkowe, ekrany komputerów i całą gamę nowoczesnych urządzeń, umożliwiających oglądanie czy słuchanie publicznych programów, za korzystanie z których trzeba płacicic ${ }^{13}$. Rozwiązaniem tego problemu może być przykład najnowszych zmian w ustawodawstwie medialnym Niemiec, omawiany przez autora w końcowej części artykułu.

Zdaniem autora poszukiwanie źródeł efektywnego finansowania mediów publicznych wymaga wydzielenia z programu tej części misji, która jest czysto usługowa, a więc polega chociażby na prezentowaniu wystąpień polityków w różnych formach programowych, wynikających z ustawowego obowiązku nadawców publicznych w zakresie informowania o życiu politycznym kraju. Środki na produkcję programów publicystycznych $\mathrm{z}$ ich udziałem mogłyby pochodzić np. $\mathrm{z}$ budżetów poszczególnych ministerstw. Częścią misji nadawcy publicznego, finansowanej z abonamentu, powinna w opinii autora pozostać sfera promowania kultury czy podejmowania na antenie spraw społecznych, budzących powszechne zainteresowanie.

W ocenie autora miarą niezależności mediów publicznych jest bez wątpienia model ich finansowania. W Polsce największym zagrożeniem dla niezależności mediów publicznych nie jest presja polityczna, lecz postępująca komercjalizacja oferty programowej, wobec malejących wpływów z abonamentu. Wpływy nadawców publicznych $\mathrm{z}$ reklamy stanowią ponad $70 \% \mathrm{w}$ strukturze ich przychodów, podczas gdy abonament wypełnia pozostałe 30\%. Ewentualna poprawa kondycji finansowej nadawców publicznych wymaga więc interwencji państwa, stosownie do ustalonych przez Komisję Europejską kryteriów dotyczących pomocy publicznej. Każda propozycja zmiany zasad finansowania mediów publicznych musi być jednak zgłoszona do Dyrekcji Generalnej ds. Konkurencji (Directorate General for Competition) w Komisji Europejskiej, co bez wątpienia wywoła nową dyskusję polityczną na temat dopuszczalnego poziomu subsydiowania nadawców publicznych przez państwo, stosownie do obowiązujących w Unii zasad dotyczących ochrony konkurencji.

\section{MODELE FINANSOWANIA NADAWCÓW PUBLICZNYCH W WYBRANYCH KRAJACH EUROPEJSKICH}

Stosownie do zaleceń Rady Europy, wynikających z głównych założeń polityki medialnej Unii Europejskiej, państwa członkowskie mogą tworzyć własne systemy finansowa-

\footnotetext{
12 Strategia regulacyjna KRRiT na lata 2011-2013, [online] ww.krrit.gov.pl, 31 I 2013.

13 Zob.: K. Jakubowicz, Unia Europejska a media..., s. 179-191.
} 
nia nadawców publicznych. Swobodę w doborze systemu finansowania publicznych środków masowego komunikowania gwarantują m.in. dokumenty Rady Europy, w tym zalecenie Komitetu Ministrów na temat gwarancji niezależności nadawców publicznych z 1996 r. ${ }^{14}$ oraz deklaracja polityczna Komitetu Ministrów z dnia 26 września 2006 r. ${ }^{15}$

W świetle zapisów tych dokumentów na państwach członkowskich spoczywa obowiązek zapewnienia bezpiecznego i przejrzystego systemu finansowania mediów publicznych, który gwarantowałby wypełnianie powierzonych im ustawowo obowiązków misyjnych. Może to być finansowanie ze środków publicznych, a więc $\mathrm{z}$ abonamentu lub dotacji budżetowych albo z reklamy bądź z innej działalności komercyjnej nadawców ${ }^{16}$. Najczęstszą formą finansowania przyjętą przez państwa członkowskie jest system mieszany, obejmujący zarówno środki publiczne, jak i dochody z reklam.

$Z$ treści opracowania autorstwa Krajowej Rady Radiofonii i Telewizji wynika ${ }^{17}$, że powszechną formą finansowania działalności mediów publicznych w państwach europejskich są także dotacje budżetowe. Obok krajów, gdzie środki te stanowią główne źródło finansowania (np. Belgia ${ }^{18}$, Bułgaria, Estonia, Portugalia, Węgry), są też państwa, które przyznając środki budżetowe, w niewielkim stopniu wspierają nadawców publicznych (np. Austria, Czechy, Dania, Polska, Szwajcaria). Wyłącznie z abonamentu i dotacji budżetowych, a więc bez udziału wpływów z reklamy, finansowani są nadawcy publiczni w Wielkiej Brytanii, Szwecji, Norwegii, Finlandii i Danii ${ }^{19}$.

W opinii Krajowej Rady najczęściej stosowanym rozwiązaniem jest jednoczesne finansowanie działalności misyjnej z trzech niezależnych źródeł: środków abonamentowych, środków budżetowych oraz dochodów z reklamy (np. Austria, Niemcy, Polska, Portugalia, Szwajcaria ${ }^{20}$. Procentowy udział tych trzech źródeł finansowania w budżecie nadawców publicznych jest oczywiście zróżnicowany w poszczególnych państwach. Przykładem kraju, który zdecydował się na finansowanie nadawców publicznych wyłącznie ze środków budżetowych, jest Estonia, a jedynie z dochodów reklamowych - Luksemburg ${ }^{21}$.

14 Zob.: Recommendation No. R (96) 10 on the Guarantee of the Independence of Public Service Broadcasting and its Explanatory Memorandum, [online] http://www.coe.int/t/dghl/standardsetting/media/Doc/CM_en.asp, 31 I 2013.

15 Declaration of the Committee of Ministers on the Guarantee of the Independence of Public Service Broadcasting in the member states, adopted on 27 September 2006, [online] http://www.coe.int/t/ $\mathrm{dghl} /$ standardsetting/media/Doc/CM_en.asp, 31 I 2013.

16 Strategia regulacyjna KRRiT na lata 2011-2013.

17 A. Woźniak [et al.], Finansowanie mediów audiowizualnych..., s. 8-10.

18 W Belgii obowiązują dwa odrębne systemy dla Walonii i Flandrii. W Luksemburgu nie występuje klasyczny nadawca publiczny. Komercyjny nadawca Radiotelevision Luksemburg (RTL) realizuje część obowiązków misji publicznej.

19 E. Stasiak-Jazukiewicz, M. Jas-Koziarkiewicz, Polityka medialna w Unii Europejskiej, Warszawa 2011, s. 111-544, Europeistyka.

20 A. Woźniak [i in.], Systemy poboru optat abonamentowych..., s. 5.

${ }_{21}$ Zob. też: Wybrane zagraniczne systemy medialne; Media masowe na świecie. Modele systemów medialnych $i$ ich dynamika rozwojowa, red. B. Dobek-Ostrowska, Wrocław 2011; J. Adamowski, Czwarty stan...; D. Hallin, P. Mancini, Systemy medialne... 
System abonamentowy jest powszechnie stosowany w większości państw europejskich, a w ponad połowie krajów badanych w omawianym raporcie Krajowej Rady stanowi dominujące źródło finansowania nadawcy publicznego. Istnieje on w większości państw członkowskich UE, za wyjątkiem takich państw jak Belgia, Bułgaria, Hiszpania, Holandia, Litwa, Łotwa, Luksemburg. W niektórych krajach postanowiono zupełnie zrezygnować z systemu abonamentowego na rzecz dotacji budżetowych (np. Holandia, Belgia, Estonia) bądź też tego rodzaju system nigdy się nie wykształcił (przykładem może być Bułgaria ${ }^{22}$ czy Litwa). ${ }^{23}$

O europejskim charakterze systemu abonamentowego może świadczyć również fakt, iż spośród 13 cztonków zatożonego w 2006 r. Stowarzyszenia ds. Abonamentu (Broadcasting Fee Association, BFA) 11 pochodzi z Europy ${ }^{24}$. Członkami BFA są następujące państwa: Austria, Czechy, Dania, Finlandia, Irlandia, Izrael, Niemcy, Norwegia, RPA, Szwajcaria, Szwecja, Wielka Brytania, Włochy. BFA ma swoją siedzibę w Wiedniu ${ }^{25}$.

System poboru abonamentu może być odrębny (np. Dania, Niemcy, Polska, Wielka Brytania czy Włochy), może też być wliczany np. do opłat za elektryczność (m.in. Grecja i Portugalia) czy do podatku katastralnego (np. Francja).

W niektórych państwach model finansowania mediów z abonamentu wyklucza całkowitą emisję reklam przez nadawcę publicznego, np. BBC (Wielka Brytania), YLE (Finlandia), SVT (Szwecja) ${ }^{26}$, NRK (Norwegia) czy ČT (Czechy), i stanowi najważniejsze źródło ich finansowania. W pozostałych przypadkach budżety nadawców mogą być uzupełniane wpływami ze sprzedaży reklam.

Omawiana analiza autorstwa Krajowej Rady wskazuje, że część państw, które postanowiły finansować nadawców publicznych ze sprzedaży czasu reklamowego, zdecydowała się wprowadzić dodatkowe ograniczenia w tym zakresie, np. limit czasu nadawania reklam (np. Niemcy, Węgry i Portugalia), zakaz przerywania reklamami niektórych audycji (np. Niemcy, Hiszpania) czy zakaz emisji reklam w konkretne dni lub w określonych porach dnia (np. Niemcy). Generalnie jednak, gdy państwa zdecydowały się przyjąć system abonamentowy, środki z tego źródła stanowią najczęściej większą część budżetu nadawcy. Wyjątkiem w tym względzie są Polska i Węgry.

Największy udział środków publicznych w strukturze przychodów radia i telewizji można obserwować w przypadku Norwegii, Danii, Szwecji, Finlandii, Niemiec (ARD i ZDF), Portugalii, Wielkiej Brytanii (BBC), Francji (France 3), Holandii, Szwajcarii, Czech i Austrii, gdzie abonament stanowi główne źródło finansowania i bywa uzupełniany środkami budżetowymi ${ }^{27}$. Najniższy udział środków publicznych jest charaktery-

22 Zob.: A. Nowosad, Wtadza i media w Butgarii, Kraków 2008, s. 384-398.

A. Woźniak [i in.], Systemy poboru optat abonamentowych..., s. 5.

24 Tamże.

25 Zob.: oficjalna strona BFA, [online] www.broadcastingfee.com, 31 I 2013.

26 Zob.: P. Szostok, Środki masowego komunikowania na przyktadzie systemów medialnych Szwecji i Norwegii, [w:] Mato znane systemy medialne, red. Z. Oniszczuk, M. Gierula, Sosnowiec 2007. 
styczny dla nadawców publicznych w Polsce, Hiszpanii, Irlandii i we Włoszech, czego efektem jest wciąż postępująca komercjalizacja oferty programowej ${ }^{28}$.

Sama opłata abonamentowa także występuje w różnych formach. W wielu państwach tradycyjnie jest ona powiązana z posiadaniem odbiornika radiowego i/lub telewizyjnego (np. w Austrii), lecz w niektórych państwach obowiązek ten rozszerzono i jest on obecnie związany z możliwością odbioru sygnału telewizyjnego i/lub radiowego bez względu na rodzaj odbiornika (np. w Irlandii, Szwajcarii i Niemczech ${ }^{29}$ ). W ten sposób część państw odpowiedziała na wyzwania związane z procesem konwergencji, dzięki któremu oferta programowa mediów publicznych dostępna jest za pomocą innych niż tradycyjne odbiorników, np. poprzez urządzenia ruchome czy Internet.

Określanie wysokości opłaty abonamentowej należy do kompetencji krajowych parlamentów (np. w Norwegii, Szwecji czy Słowacji) lub odpowiednich ministrów (np. w Irlandii czy Wielkiej Brytanii). Wysokość tych opłat jest różna w zależności od wybranego systemu finansowania mediów publicznych oraz poziomu zamożności danego społeczeństwa ${ }^{30}$.

$\mathrm{Z}$ szacunkowych danych przedstawionych w omawianym raporcie przez Krajową Radę wynika, że najwyższy roczny abonament telewizyjny jest w Szwajcarii (ponad 300 euro), w krajach skandynawskich (od 290 euro w Danii, 270 euro w Norwegii, 240 w Szwecji, do 215 euro w Finlandii). W Austrii wynosi on 240 euro, w Niemczech 210 euro, w Wielkiej Brytanii 200 euro, w Irlandii 175 euro, we Francji 120 euro, we Włoszech 105 euro, w Polsce i w Czechach 50 euro, na Słowacji 35 euro $^{31}$.

Opłata abonamentowa jest więc najwyższa i stanowi jednocześnie największe obciążenie dla obywateli w Szwajcarii i Danii, a także w takich państwach jak Austria ${ }^{32}$ czy Szwecja. Na drugim końcu tego zestawienia znajdują się takie państwa, jak: Słowacja, Czechy, Włochy i Polska ${ }^{33}$.

Pod względem organizacyjnym system poboru abonamentu został różnie rozwiązany w poszczególnych państwach europejskich ${ }^{34}$. W wielu przypadkach nadawcy publiczni są bezpośrednio zaangażowani w proces zbierania opłaty abonamentowej (np. DR w Danii

28 A. Jaskiernia, Publiczne media elektroniczne w Europie, Warszawa 2006, s. 250-268.

29 B. Ociepka, System medialny Niemiec, [w:] Wybrane zagraniczne systemy medialne, s. 108; zob. też: M. Ratajczak, Jak porozumiewaja się Szwajcarzy? Media w wielokulturowej Szwajcarii, Wrocław 2004, s. 95-104, Acta Universitatis Wratislaviensis, nr 2651.

30 Zob.: Communications Act 2003, c. 21; Ustawa z dnia 21 kwietnia 2005 r. o opłatach abonamentowych, art. 1; Wyrok Trybunału Konstytucyjnego z 16 marca 2010 r. w sprawie zgodności z Konstytucją artykułu 7 ustawy o opłatach abonamentowych, sygn. akt K 24/08 22/3/A/2010.

31 A. Woźniak [i in.], Systemy poboru optat abonamentowych..., s. 9.

32 Por.: Raport roczny ORF, Wert über Gebühr, Public Value Bericht, 2010/2011, [online:] http://www. orf.at, 31 I 2013.

33 Zob.: Sprawozdanie Krajowej Rady Radiofonii i Telewizji z dziatalności w 2010 roku, Warszawa 2011; Informacja o podstawowych problemach radiofonii i telewizji w 2010 roku, Warszawa 2011.

34 Dyrektywa Parlamentu Europejskiego i Rady 2010/13/UE z dnia 10 marca 2010 r. w sprawie koordynacji niektórych przepisów ustawowych, wykonawczych i administracyjnych państw członkowskich dotyczących świadczenia audiowizualnych usług medialnych (dyrektywa o audiowizualnych usługach medialnych). 
czy NRK w Norwegii) lub też odbywa się to pośrednio poprzez specjalnie powołane spółki zależne (np. GIS w Austrii czy RIKAB w Szwecji). Rola ta przypada także urzędom pocztowym (np. w Polsce, Irlandii czy na Słowacji), regulatorom rynku (np. FICORA w Finlandii) czy wreszcie prywatnym firmom (np. w Szwajcarii i Wielkiej Brytanii).

Wszystkie wymienione podmioty posiadają także w większości przypadków uprawnienia związane z monitorowaniem oraz kontrolą poziomu ściągalności abonamentu i mogą nakładać kary pieniężne lub kierować sprawę do sądu. Często podmioty te wyposażone są w specjalną aparaturę radiolokacyjną, umożliwiającą identyfikację gospodarstw domowych uchylających się od płacenia abonamentu (np. w Danii ${ }^{35}$ i Wielkiej Brytanii $\left.{ }^{36}\right)$, skąd nielegalnie odbierany jest sygnał radiowy i telewizyjny.

Środki abonamentowe nie zawsze trafiają bezpośrednio do budżetów nadawców publicznych. W wielu przypadkach są one dzielone przez instytucje państwowe lub zasilają różnego rodzaju fundusze (np. w Finlandii), z których dopiero trafiają do beneficjentów. Nie zawsze środki abonamentowe przeznaczane są jedynie na działalność nadawców publicznych. W niektórych przypadkach w części zasilają także budżety regulatorów rynku (np. w Niemczech Landesmedienanstalten ${ }^{37}$, OFCOM w Szwajcarii czy Rundfunk und Telekom Regulierungs $\mathrm{GmbH}$ w Austrii ${ }^{38}$ ) lub są przekazywane po części innym nadawcom spełniającym specyficzne warunki w zakresie realizacji misji publicznej (np. w Irlandii czy w Szwajcarii).

Krajowa Rada podkreśla, że mimo różnic w zorganizowaniu systemów abonamentowych w poszczególnych państwach kwestia ściągalności abonamentu pozostaje wspólnym problemem. Odsetek osób uchylających się od płacenia abonamentu w większości państw wynosi w przybliżeniu 10\%, choć np. w Szwajcarii i Wielkiej Brytanii procent ten jest niższy. Na przeciwległym biegunie znajdują się Polska i Włochy ${ }^{39}$, gdzie regularnie abonament płaci ok. $25 \%$ gospodarstw domowych, natomiast w przypadku firm $\mathrm{i}$ instytucji jest to mniej niż 5\%.

Telewizyjni nadawcy publiczni w większości państw europejskich zajmują istotne miejsce na krajowym rynku medialnym. W niektórych przypadkach ich udział w krajowych rynkach oglądalności przekracza 40\%. Największą oglądalnością cieszą się telewizje publiczne z Polski, Austrii, Finlandii, Włoch, Norwegii i Niemiec. Najniższą oglądalność ma publiczna telewizja węgierska MTV. W tym kontekście warto zauważyć, że we wszystkich z tych państw istnieje system abonamentowy. Jednak, co istotne, jedynie w Finlandii, Norwegii i w Niemczech udział środków publicznych w budżetach nadawców publicznych jest wysoki i przekracza $80 \%$. W przypadku pozostałych trzech państw uwagę zwraca wysoki poziom finansowania ze źródeł komercyjnych. Najniższy

35 E. Stasiak-Jazukiewicz, M. Jas-Koziarkiewicz, Polityka medialna w Unii Europejskiej, s. 205.

36 Tamże, s. 506-510.

37 B. Ociepka, System medialny Niemiec, s. 92.

38 Zob.: B. Ociepka, M. Ratajczak, Media i komunikowanie polityczne. Niemcy, Austria, Szwajcaria, Wrocław 2000.

39 Por.: Sprawozdanie roczne AGCOM 2010 (Relazione annuale sull'attivita' svolta e sui programmi di lavoro), [online] www.agcom.it, 31 I 2013. 
udział w rynku oglądalności mają nadawcy publiczni z Węgier, Słowacji, Hiszpanii i Portugalii (poniżej 30\%) ${ }^{40}$.

Matteo Maggiore, dyrektor ds. europejskich i międzynarodowych BBC, prezentując w 2008 r. na konferencji w Warszawie ${ }^{41}$ model finansowania nadawcy publicznego w Wielkiej Brytanii, podkreślił, że w efekcie oceny statutu BBC porozumiano się z rządem w sprawie finansowania tej telewizji, ponieważ uznano, że sprawdzonym sposobem zachowania niezależności BBC i utrzymania wysokiego poziomu produkcji programowej są wpływy z abonamentu. Rząd brytyjski w porozumieniu ze społeczeństwem zdecydował, że BBC będzie finansowane $\mathrm{z}$ abonamentu przez kolejne 10 lat $^{42}$. Ustalono, że w tym okresie BBC otrzyma z tego tytułu blisko 20 mld funtów ${ }^{43}$.

Maggiore w swoim wystąpieniu podkreślił, że abonament jest ważny, pod warunkiem, że jest wystarczający. Sprawia bowiem, że media odpowiadają przed społeczeństwem. Żadne inne usługi publiczne nie mają tak bezpośredniego z nim połączenia: Ptacąc podatki na stużbę zdrowia, nie daje się pieniędzy na szpitale, ptacac podatki na edukacje, nie finansuje się bezpośrednio szkót, ale optacając abonament telewizyjny w Wielkiej Brytanii, ma siępewność, że te pieniadze trafia tylko do $B B C$ - stwierdził dyrektor ds. europejskich i międzynarodowych brytyjskiego nadawcy publicznego. Zdaniem Maggiore'a istotne jest, by ustalenia dotyczące finansowania były długoterminowe. Krótkoterminowe sprawiają bowiem, że medium publiczne co roku musi walczyć o przetrwanie.

Inny model działalności telewizji publicznej przedstawił podczas konferencji w Warszawie ${ }^{44}$ przedstawiciel francuskiego nadawcy publicznego France Télévisions ${ }^{45}$, przypominając, iż w 2007 r. ówczesny prezydent Francji Nicolas Sarkozy ${ }^{46}$ oczekiwał zlikwidowania reklam na antenie France Télévisions ${ }^{47}$.

40 Zob.: Financialsituation of TV companies, [w:] Yearbook 2011, t. 1: Television in 37 Countries, European Audiovisual Observatory, 2011, [online] www.obs.coe.int, 31 I 2013.

41 M. Maggiore, Rola i znaczenie mediów publicznych $w$ Europie. Materiaty z konferencji KRRiT, Warszawa 2009, [online] http://www.krrit.gov.pl/Data/Files/_public/Portals/0/konferencje/dm_ konf_080415_spraw.pdf, 31 I 2013.

42 Zob.: Royal Charter or the Continuance of the British Broadcasting Corporation, Presented to Parliament by the Secretary of State for Culture, Media and Sportby Command of Her Majesty, Department For Culture, Media And Sport, October 2006, [online] www. bbc.co.uk, 31 I 2013.

43 Communications Act 2003, c. 21; Kodeks nadawania OFCOM z 2010 r. (The Ofcom Broadcasting Code), [online] www.ofcom.co.uk, 31 I 2013. Zob. też: E. Stasiak-Jazukiewicz, M. Jas-Koziarkiewicz, Polityka medialna w Unii Europejskiej, s. 504-506, 509-510.

44 Rola i znaczenie mediów publicznych w Europie. Materiaty z konferencji KRRiT, Warszawa 2009, [online] http://www.krrit.gov.pl/Data/Files/_public/Portals/0/konferencje/dm_konf_080415_spraw. pdf, 31 I 2013.

45 Zob.: oficjalna strona France Télévisions: [online] www.francetelevisions.fr, 31 I 2013.

46 Zob.: Le Président de la République, Nicolas Sarkozy, a fixé des objectifspour l'audiovisuel dans une lettre adressée le $1^{\text {er }}$ août 2007 au ministre de la Culture et de la Communication, [online] www.francetelevisions.fr, 31 I 2013.

47 Por.: Ustawa z 5 marca 2009 r. (Loi nº 82-652 du 29 juillet 1982 sur la communication audiovisuelle), ostatnia zmiana z 10 lutego 2010 r., [w:] E. Stasiak-Jazukiewicz, M. Jas-Koziarkiewicz, Polityka medialna w Unii Europejskiej, s. 235-236. 
Prezydent uznał, że likwidacja reklam $w$ telewizji publicznej pozwolitaby na podjęcie nowych zadań $w$ dziedzinie sztuki i kultury, a przede wszystkim na potraktowanie w sposób bardziej wymagajacy problemów wspótczesnego świata. W opinii prezydenta Francji trzeba dążyć do tego, by telewizja stała się bardziej innowacyjna ${ }^{48}$. W tym celu należało więc zbadać inne możliwe źródła finansowania nadawcy, które zastąpiłyby zyski z reklam, nie wymuszając na mediach publicznych konieczności komercjalizacji programu, podyktowanej silną konkurencją. Jedną z rozważanych hipotez miała być m.in. sprzedaż części udziałów w holdingu France Télévisions operatorom telefonii komórkowych.

Od 2008 r., na mocy dekretu prezydenta, media publiczne we Francji nie mogły więc nadawać reklam w godz. 20.00-6.00. Zostało to jednak zakwestionowane przez Trybunał Konstytucyjny. Dnia 11 lutego 2010 r. francuski Trybunał Konstytucyjny wydał orzeczenie (Decision du Conseil d'Etat nr 324233) uchylające pisemne polecenie Ministra Kultury i Komunikacji dotyczące wycofania z telewizji publicznej reklam, począwszy od 5 stycznia 2009 r., oraz uchwałę Rady Administracyjnej Grupy France Télévisions przyjmującą polecenie w powyższej sprawie oraz zlecającą jego wykonanie prezesowi Grupy. Powodem unieważnienia obu dokumentów było stwierdzenie, że ani Minister Kultury, ani Rada Administracyjna nadawcy publicznego nie mieli prawa decydować o wstrzymaniu nadawania reklam w telewizji publicznej bez podstawy prawnej $w$ formie ustawy, pozostającej wówczas jeszcze w toku prac legislacyjnych ${ }^{49}$. Obecny model organizacji działalności nadawców publicznych we Francji, wraz z systemem ich finansowania, autor omawia w kolejnej części artykułu.

\section{MODELE ROZWIĄZAŃ W ZAKRESIE POBORU ABONAMENTU NA PRZYKŁADZIE WYBRANYCH PAŃSTW EUROPEJSKICH}

\section{A. Struktura organizacyjna i model finansowania nadawców publicznych w Polsce}

W wyniku przemian politycznych po r. 1989, w toku prac legislacyjnych nad Ustawą o radiofonii i telewizji, spośród różnych wariantów formy prawnej mediów publicznych ostatecznie wybrano jednoosobową spółkę akcyjną Skarbu Państwa, reprezentowanego w niej przez Ministra Skarbu Państwa ${ }^{50}$. Odrzucono formułę przedsiębiorstwa państwowego, fundacji i korporacji publicznej ${ }^{51}$. W okresie PRL, od 1960 r., status prawny

48 Zob.: Raport Commission pour la nouvelle télévision publique, présenté au Président de la République par Jean-François Copéle 25 juin 2008, [online] www.culturecommunication.gouv.fr; Raport Rapport Public Thématique - France Télévisions et la Nouvelle Télévision Publique, Octobre 2009, [online] http://www.ccomptes.fr/fr/CC/documents/RPT/RPT-France-televisions.pdf, 31 I 2013.

49 E. Stasiak-Jazukiewicz, M. Jas-Koziarkiewicz, Polityka medialna w Unii Europejskiej, s. 236.

50 I. Dobosz, Prawo prasowe, Warszawa 2011, s. 124, Seria Akademicka; taż, Prawne aspekty transformacji w mediach, [w:] Polskie media w jednoczącej się Europie. Szanse i wyzwania, red. I. Dobosz, B. Zając, Kraków 2006, s. 11-16; Prawo mediów, red. J. Barta, R. Markiewicz, A. Matlak, Warszawa 2008, s. 142-147.

51 M. Miżejewski, Transformacja telewizji w Polsce po roku 1989 na tle zmian politycznych, Przemyśl 2005, s. 11-15. 
państwowego radia i telewizji określała Ustawa o Radiokomitecie ${ }^{52}$. Radio i telewizja stanowiły wówczas jedną instytucję, dla której ustawodawca przyjął wspólną strukturę organizacyjną. Był to centralny organ administracji państwowej, działający przy Radzie Ministrów i podporządkowany premierowi.

Obecną strukturę organizacyjną i status prawny nadawców publicznych określa Ustawa o radiofonii i telewizji z dnia 29 grudnia $1992 \mathrm{r}^{53}$ Telewizja jest jednoosobową spółką akcyjną Skarbu Państwa, wraz z oddziałami terenowymi (początkowo było ich 11, a obecnie jest 16), nieposiadającymi osobowości prawnej. Oddziały terenowe spółki TVP SA działają w Białymstoku, Bydgoszczy, Gorzowie Wielkopolskim, Gdańsku, Katowicach, Kielcach, Krakowie, Lublinie, Łodzi, Opolu, Olsztynie, Poznaniu, Rzeszowie, Szczecinie, Warszawie i we Wrocławiu ${ }^{54}$.

Zgodnie z art. 26 Ustawy o radiofonii i telewizji Telewizja Polska SA jest jedna spót$k a$, powotana $w$ celu tworzenia i rozpowszechniania programów ogólnokrajowych, a takze regionalnych programów telewizyjnych. TVP SA ma więc strukturę centralistyczną, z główną siedzibą w Warszawie.

System radiofonii publicznej tworzą natomiast spółka Polskie Radio w Warszawie oraz 17 odrębnych spółek radiofonii regionalnej. Radiofonia publiczna, w odróżnieniu od telewizji, ma zdecentralizowaną strukturę organizacyjną, działając w dwóch niezależnych od siebie formach prawnych. Zgodnie z ustawą spółka Polskie Radio SA z siedzibą w Warszawie została zawiązana w celu tworzenia i rozpowszechniania ogólnokrajowych programów radiowych i programów dla odbiorców za granicą. Spółki radiofonii regionalnej są natomiast odrębnymi spółkami Skarbu Państwa, posiadającymi osobowość prawną (np. Radio Kraków Małopolska).

Działalność nadawców publicznych jako spółek prawa handlowego regulują więc zarówno Ustawa o radiofonii i telewizji ${ }^{55}$, jak i Kodeks spółek handlowych ${ }^{56}$.

Uchwała Trybunału Konstytucyjnego z dnia 13 grudnia 1995 r., przyjęta na wniosek ówczesnego prezydenta Lecha Wałęsy, o ustaleniu powszechnie obowiązującej wykładni art. 26 i 28 Ustawy o radiofonii i telewizji, minimalizuje wynikającą stąd sprzeczność, wskazując, że dziatalność gospodarcza spótek publicznej radiofonii i telewizji (a więc finansowanie części programu z reklamy) ma charakter drugoplanowy i pomocniczy w stosunku do celów określonych w ustawie ${ }^{57}$. Według opinii Karola Jakubowicza ustawa o radiofonii i telewizji naktada na nadawców publicznych niekomercyjne cele programowe, ko-

52 Ustawa z 2 grudnia 1960 r. o Komitecie do spraw Radia i Telewizji „Polskie Radio i Telewizja” (Dz. U. 1960, nr 54, poz. 307 z późn. zm).

53 Ustawa z dnia 29 grudnia 1992 r. o radiofonii i telewizji (Dz. U. 2004, nr 253, poz. 2531 z późn. zm.).

54 I. Dobosz, Prawo prasowe, s. 127.

55 Ustawa z dnia 29 grudnia 1992 r. o radiofonii i telewizji (art. 26, ust. 2); I. Dobosz, Prawo prasowe, s. 79-86.

56 Do spółek radiofonii i telewizji publicznej stosuje się z zastrzeżeniem art. 27-30 przepisy Ustawy z dnia 15 września 2000 r. Kodeks spółek handlowych (Dz. U. 2000, nr 94, poz. 1037 z późn. zm.).

57 Uchwała Trybunału Konstytucyjnego z dnia 13 grudnia 1995 r. dotycząca ustalenia powszechnie obowiązującej wykładni przepisów art. 26 ust. 4 i art. 28 ust. 1 (zdanie drugie) Ustawy z dnia 29 grudnia 1992 r. o radiofonii i telewizji (Dz. U. 1996, nr 2, poz. 15). 
deks spótek handlowych bywa więc interpretowany, nie do końca stusznie, jako wymagający od nadawców publicznych osiagania zysku ${ }^{58}$.

Autor w pełni podziela to stanowisko. Realizacja misji przez nadawców publicznych określona w art. 21 Ustawy medialnej powinna być zadaniem priorytetowym. Rolą państwa jest więc stworzenie efektywnego modelu ich finansowania, gwarantującego stabilność funkcjonowania. W przeciwnym razie publicznej radiofonii i telewizji grozi komercjalizacja.

Dla ustawodawcy określającego model finansowania nadawców publicznych w Ustawie medialnej nie bez znaczenia pozostawała sprawa kontroli ich finansów. W ustawie z grudnia 1992 r. przyjęto, że głównym źródłem finansowania radiofonii i telewizji publicznej będzie abonament, a więc pieniądze publiczne. W związku z tym działalność radiofonii i telewizji mogła podlegać ustawowej kontroli NIK (Najwyższej Izby Kontroli ${ }^{59}$ pod względem legalności, gospodarności, celowości i rzetelności w zakresie, w jakim radiofonia i telewizja wykorzystywałyby majątek lub środki państwowe oraz wywiązywałyby się ze zobowiązań finansowych na rzecz państwa. Gdyby radiofonia lub telewizja były spółkami prawa handlowego, niekorzystającymi z pieniędzy publicznych, przeprowadzenie takiej kontroli przez NIK byłoby niemożliwe. Zakres kompetencji Najwyższej Izby Kontroli w tym zakresie znalazł także umocowanie w Konstytucji RP z 1997 r. w art. $203^{60}$.

W opinii autora struktura organizacyjna telewizji publicznej, której integralną częścią pozostają oddziały terenowe, utrudnia ewentualną prywatyzację ośrodków regionalnych, choć były takie plany na mocy Ustawy o komercjalizacji i prywatyzacji przedsiębiorstw państwowych z dnia 30 sierpnia 1996 r. $^{61}$ Ośrodki te musiałyby uzyskać osobowość prawną. Prywatyzacja w rozumieniu ustawy polegałaby na zbywaniu należących do Skarbu Państwa akcji spółek powstałych w wyniku komercjalizacji. Zgoda na ewentualną prywatyzację mogłaby udzielić tylko Rada Ministrów, która w art. 1 ust. 3 ustawy zastrzegła sobie jednak prawo do określenia w drodze rozporządzenia tego, które jednoosobowe spółki akcyjne Skarbu Państwa mają szczególne znaczenie dla gospodarki. Na tej liście mogłyby więc znaleźć się wybrane spółki ośrodków regionalnych telewizji.

Obecnie zasady poboru abonamentu nie reguluje już Ustawa o radiofonii i telewizji, ale odrębny akt prawny: Ustawa z dnia 21 kwietnia 2005 r. o opłatach abonamentowych $^{62}$. Artykuł 1 ustawy określa cel poboru abonamentu oraz jego beneficjenta. $Z$ treści artykułu wynika, że optaty abonamentowe pobiera się w celu umożliwienia realizacji misji publicznej [...] przez jednostki publicznej radiofonii i telewizji.

58 K. Jakubowicz, Publiczna i prywatna telewizja, [w:] Media i dziennikarstwo w Polsce 1989-1995, red. G. Kopper, I. Rutkiewicz, K. Schliep, Kraków 1996, s. 64.

59 Ustawa z dnia 23 grudnia 1994 r. o Najwyższej Izbie Kontroli (Dz. U. 1995, nr 13, poz. 59 z późn. zm.).

60 Konstytucja RP z dnia 2 kwietnia 1997 r. (Dz. U. 1997, nr 78, poz. 483).

${ }_{61}$ Ustawa z dnia 30 sierpnia 1996 r. o komercjalizacji i prywatyzacji przedsiębiorstw państwowych (Dz. U. 1996, nr 118, poz. 561).

62 Ustawa z dnia 21 kwietnia 2001 r. o opłatach abonamentowych (Dz. U. 2005, nr 85, poz. 728 z późn. zm.). 
Spółki publicznej radiofonii i telewizji są więc w Polsce wyłącznymi beneficjentami opłaty abonamentowej. Wpływy z abonamentu maleją jednak z każdym rokiem. Jest to rezultat m.in. braku skutecznego mechanizmu prawnej egzekucji tej należności ze strony państwa. W strukturze przychodów nadawców publicznych abonament stanowi mniej niż 30\%, czyli znacznie poniżej $500 \mathrm{mln}$ zł rocznie. Pozostałe $70 \%$ zajmują wplywy z reklamy.

Zgodnie z ustawą opłaty abonamentowe pobiera się za używanie odbiorników radiofonicznych oraz telewizyjnych, które podlegają rejestracji. Opłatę uiszcza się za każdy odbiornik telewizyjny i radiowy (przepis ten nie dotyczy osób będących we wspólnym gospodarstwie domowym, a także publicznych zakładów opieki zdrowotnej, sanatoriów, żłobków, placówek oświatowych, szkół wyższych, domów pomocy społecznej) ${ }^{63}$.

Zgodnie z art. 3 ust. 2 ustawy wysokość abonamentu określa rozporządzeniem Krajowa Rada Radiofonii i Telewizji do dnia 31 maja każdego roku na następny rok kalendarzowy i ogłasza ją w „Monitorze Polskim”. W r. 2013 opłata ta wynosi 5,65 zł miesięcznie za radioodbiornik i 18,65 zł za telewizor lub łącznie również 18,65 zł za radio i telewizor ${ }^{64}$.

Poborem abonamentu i kontrolą wykonywania tego obowiązku zajmuje się operator publiczny w rozumieniu Ustawy z dnia 12 czerwca 2003 r. Prawo pocztowe ${ }^{65}$.

Poczta Polska przekazuje Krajowej Radzie Radiofonii i Telewizji wpływy z opłat oraz odsetek za zwłokę. Podziałem abonamentu pomiędzy jednostki publicznej radiofonii i telewizji zajmuje się Krajowa Rada. Jej działalność nie jest jednak finansowana $\mathrm{z}$ abonamentu, lecz z budżetu państwa (zgodnie z art. 11 ust. 3 Ustawy o radiofonii i telewizji).

W marcu 2010 r. Trybunał Konstytucyjny orzekt ${ }^{66}$, że art. 7 ust. 3 i 6 Ustawy z dnia 21 kwietnia 2005 r. o opłatach abonamentowych są zgodne z art. 2 Konstytucji Rzeczypospolitej Polskiej, który mówi, że Rzeczpospolita Polska jest demokratycznym państwem prawnym, urzeczywistniajacym zasady sprawiedliwości spotecznej. Uzasadniając wyrok, Trybunał Konstytucyjny dokonał analizy charakteru prawnego opłat abonamentowych oraz kompetencji organów państwa właściwych w sprawach poboru tych opłat. Wśród przychodów mediów publicznych na pierwszym miejscu zo-

\footnotetext{
63 I. Dobosz, Prawo prasowe, s. 148.
}

64 Rozporządzenie KRRiT z dnia 7 maja 2012 r. w sprawie wysokości opłat abonamentowych za używanie odbiorników radiofonicznych i telewizyjnych oraz zniżek za ich uiszczanie z góry za okres dłuższy niż jeden miesiąc w 2013 r., [online] http://www.krrit.gov.pl/dla-nadawcow-i-operatorow/regulacje-prawne/polska/abonament-rtv, 31 I 2013.

65 Ustawa z dnia 12 czerwca 2003 r. Prawo pocztowe (tekst jednolity: Dz. U. 2008, nr 189, poz. 1159 z późn. $z m$.).

66 Wyrok z 16 marca 2010 r. Trybunatu Konstytucyjnego po rozpoznaniu, z udziatem wnioskodawcy oraz przedstawicieli Sejmu RP i Prokuratora Generalnego, na rozprawach 17 listopada i 10 grudnia 2009 r. oraz 16 marca 2010 r., wniosku Rzecznika Praw Obywatelskich o zbadanie zgodności art. 7 Ustawy z dnia 21 kwietnia 2005 roku o opłatach abonamentowych z art. 1, art. 2 oraz art. 84 w związku z art. 217 Konstytucji Rzeczypospolitej Polskiej, sygn. akt K 24/08 22/3/A/2010. 
stał wymieniony abonament, co pozwala sądzić, że ustawodawca uznał go za najważniejsze źródło ich finansowania ${ }^{67}$.

W poprzednim wyroku z 9 września $2004 \mathrm{r}$. Trybunał Konstytucyjny orzekł, że abonament ten to przymusowe, bezzwrotne swiadczenie publicznoprawne, stużace realizacji konstytucyjnych zadań pañstwa ${ }^{68}$. Jest to danina publiczna, różna od innych danin wskazanych w art. 217 Konstytucji RP przez swój celowy charakter, niestanowiąca dochodów państwa o charakterze stricte budżetowym. Zapewnić ma ona zarówno organowi władzy publicznej - Krajowej Radzie Radiofonii i Telewizji, jak i mediom publicznym stabilność i przewidywalność wydatków na realizację misji publicznej. Skutkiem traktowania abonamentu jako daniny publicznej są rygory w zakresie jego wprowadzenia (wyłącznie ustawą), a także obowiązek jawnego i kontrolowanego publicznie wykorzystywania płynących z niego dochodów.

Dla zapewnienia sprawnego gromadzenia środków na ten cel ustawodawca przyjął szereg dalszych rozwiązań: domniemanie używania odbiornika przez jego posiadacza, o ile odbiornik ten znajduje się w stanie umożliwiającym natychmiastowy odbiór programu (art. 2 ust. 2 Ustawy abonamentowej), ustawowy obowiązek rejestracji odbiornika (art. 5 ust. 1 Ustawy abonamentowej), powstanie obowiązku uiszczania abonamentu z pierwszym dniem miesiąca następującego po miesiącu rejestracji odbiornika (art. 2 ust. 3 Ustawy abonamentowej), wyznaczenie terminu płatności abonamentu na 25 dzień miesiąca, za który jest on należny, z możliwością jego uiszczania z góry za dłuższe okresy (z czym wiążą się zniżki; art. 3 ust. 4 i 6 Ustawy abonamentowej).

Trybunał Konstytucyjny uznał, że brak decyzji administracyjnej nie stanowi przeszkody w przeprowadzeniu egzekucji administracyjnej abonamentu. $Z$ ustawy wynikają zarówno wysokość należności z tytułu abonamentu, jak i termin płatności. Kierownik Centrum Obsługi Finansowej (COF) Poczty Polskiej SA jest wierzycielem w rozumieniu Ustawy egzekucyjnej i nie dysponuje swobodą decydowania o złożeniu albo niezłożeniu wniosku o wszczęcie egzekucji administracyjnej.

Po upływie ustawowego terminu uiszczenia abonamentu kierownik COF Poczty Polskiej wystawia tytuł wykonawczy. Winien on zostać niezwłocznie skierowany do właściwego miejscowo naczelnika urzędu skarbowego. Trybunał Konstytucyjny wskazał, że wydanie decyzji administracyjnej dotyczącej opłaty karnej jest konieczne ze względu na to, że jej adresat - podmiot, który nie dopełnił ustawowego obowiązku rejestracji odbiornika - pozostaje całkowicie poza systemem abonamentowym. W odniesieniu natomiast do podmiotu, który odbiornik zarejestrował i który tym samym znajduje się w owym systemie abonamentowym, ale nie wywiązuje się $\mathrm{z}$ ustawowego obowiązku uiszczania abonamentu - wydawanie decyzji jest zbędne.

Trybunał Konstytucyjny stwierdził, że sam wybór Poczty Polskiej SA jako podmiotu odpowiedzialnego za rejestrację odbiorników i egzekwowanie wpływów z abonamentu nie wywołuje zastrzeżeń co do dopuszczalności takiego uregulowania ani nie wyklucza

67 Ustawa z dnia 21 kwietnia 2005 r. o opłatach abonamentowych (Dz. U. 2005, nr 85, poz. 728 z późn. zm.).

68 Wyrok Trybunału Konstytucyjnego z 9 września 2004 r., sygn. akt K 2/2003. 
skuteczności podejmowanych działań. Relacjonowana w stanowiskach uczestników postępowania faktyczna nieskuteczność egzekucji, choćnaganna, nie jest równoznaczna zniekonstytucyjnością ksztattujaccej ja regulacji, zaś bezczynność określonych instytucji w ogóle nie poddaje sie kontroli w kategoriach konstytucyjnych - czytamy w uzasadnieniu decyzji Trybunału.

Zdaniem Trybunału Konstytucyjnego egzekucja - zarówno opłaty karnej, jak i należności z tytułu abonamentu - jest dopuszczalna i z punktu widzenia obowiązującego prawa możliwa, a przeciwne stanowisko organów państwa, udzielających wyjaśnień Rzecznikowi Praw Obywatelskich, jest wyrazem imposybilizmu, ponieważ w praktyce sprawia, że stosowne przepisy Ustawy abonamentowej są martwe.

Trybunał Konstytucyjny stwierdził, że w trakcie rozprawy przedstawiciel Prokuratora Generalnego sygnalizował niemożność skutecznej kontroli, spowodowaną brakiem prawa upoważnionych pracowników Poczty Polskiej do wejścia do pomieszczeń, w których mógłby się znajdować niezarejestrowany odbiornik. Zdaniem Trybunału Konstytucyjnego z pewnością nie pozostaje to bez wpływu na efektywność wykrywania podmiotów, które nie dopełniły ustawowego obowiązku rejestracji odbiornika, a ustawodawca powinien dostrzec, że pracownicy ci nie mają uprawnień do kontrolowania gospodarstw domowych bez zgody lokatorów.

W opinii Trybunału ustawodawca musi wziąć pod uwagę, że niezarejestrowanie odbiornika - jakkolwiek sprzeczne z prawem i zagrożone sankcją - nie jest przestępstwem ani wykroczeniem, więc rozwiązania prawne dotyczące przeszukania, w trybie określonym przez kodeks postępowania karnego, w tej sytuacji wydają się nieadekwatne.

\section{B. Struktura organizacyjna i model finansowania nadawców publicznych na Węgrzech}

$\mathrm{Na}$ Węgrzech działają dwie publiczne stacje telewizyjne: Magyar Televizio Rt. oraz Duna Televizio Rt., które emitują trzy telewizyjne programy ogólnokrajowe. Rozgłośnia publiczna Magyar Radio Rt. nadaje trzy radiowe programy ogólnokrajowe ${ }^{69}$.

Ustawa nr 100 z 2003 r. o lączności elektronicznej i zmieniająca ją Ustawa nr 174 z 2010 r. dostosowują prawodawstwo węgierskie do regulacji unijnych ${ }^{70}$. Ustawa z 2010 r., implementująca Dyrektywę o audiowizualnych usługach medialnych ${ }^{71}$, wprowadziła nowy system zarządzania dla nadawców publicznych. Połączyła wcześniej oddzielne podmioty medialne: Magyar Televizio, Magyar Radio i Duna Televizio w Fundację Programu Publicznego.

Finansowanie mediów publicznych na Węgrzech po zniesieniu w 2002 r. opłaty abonamentowej odbywa się z wielu różnych źródeł. Środki komercyjne stanowią jedynie 9\%

69 E. Stasiak-Jazukiewicz, M. Jas-Koziarkiewicz, Polityka medialna w Unii Europejskiej, s. 487-491.

70 Tamże, s. 491.

71 Dyrektywa Parlamentu Europejskiego i Rady Unii Europejskiej 2010/13/UE z dnia 10 marca 2010 r. w sprawie koordynacji niektórych przepisów ustawowych, wykonawczych i administracyjnych państw członkowskich dotyczących świadczenia audiowizualnych usług medialnych (Dyrektywa o audiowizualnych usługach medialnych) (Dz. U. UE L 95 z 15 kwietnia 2010 r.). 
budżetu nadawców publicznych. Pieniądze z budżetu państwa są wykorzystywane do ściśle określonych celów, np. na dotowanie orkiestry symfonicznej Węgierskiego Radia. Jedną z metod finansowania węgierskich mediów publicznych jest kupowanie dla nich usług. Budżet państwa płaci bezpośrednio węgierskiemu operatorowi telekomunikacyjnemu Antena Hungaria za dostarczanie swoich usług nadawcom publicznym ${ }^{72}$.

Środki te stanowią ok. 26\% całości finansowania. Osobliwością węgierskiego programu finansowania jest proporcja opłat nadawczych, które w części są pokrywane przez nadawców komercyjnych. Kiedy w 1996 r. tworzył się węgierski system medialny, ci właśnie nadawcy używali częstotliwości zarezerwowanych dla sektora mediów publicznych. Kwoty pobierane za korzystanie z tych częstotliwości stanowią $4 \%$ całkowitego dochodu mediów publicznych.

Największe zyski przynosiła jednak opłata abonamentowa - w wysokości ok. $90 \mathrm{mln}$ euro, co stanowiło $42 \%$ całego dochodu sektora mediów publicznych. Opłata ta została wprowadzona w 1996 r. wraz z pierwszą węgierską ustawą dotyczącą mediów publicznych $^{73}$. W swojej pierwotnej formie była to kwota ustalana przez parlament i uzależniona od liczby gospodarstw domowych. Jednak abonament płaciło ok. 40\% gospodarstw. W 2002 r. nastąpiła zmiana modelu finansowania mediów publicznych ${ }^{74}$. Abonament zniesiono, co było decyzją polityczną, podyktowaną przygotowaniami rządu do wyborów do władz lokalnych i samorządów terytorialnych. Zniesienie abonamentu było jedną z wyborczych obietnic, dzięki której chciano pozyskać głosy wyborców.

W czerwcu 2002 r. na Wegrzech zawieszono (de facto zniesiono) optaty abonamentowe, pozostawiając bankrutujaca telewizje publiczna i poważnie niedofinansowane radio publiczne zdane na pomoc państwa. Wegierska telewizja publiczna przynosita wówczas 70 tys. dolarów strat dziennie. [...] Dawanie kolejnych dotacji i umarzanie dtugów telewizji publicznej przez rzad byto odbierane jako „zaptata za ustugi” swiadczone na rzecz rzadzacej klasy politycznej ${ }^{75}$.

W 2007 r. ponownie częściowo przywrócono abonament, ale tylko dla komercyjnych użytkowników odbiorników telewizyjnych, czyli hoteli, restauracji czy pubów, które zwłaszcza w czasie transmisji sportowych przyciągają rzesze odbiorców. To jednak tylko częściowo pokrywa koszty produkcji programów przez nadawców publicznych.

Obecnie środki na produkcję programów nadawców publicznych gromadzone są w utworzonym w tym celu specjalnym funduszu. Pochodzą one w części z abonamentu (jego wysokość ustalana jest co roku przez parlament w Ustawie budżetowej), opłat koncesyjnych i rejestrowych, kar i odsetek za zwłokę związanych z tymi opłatami

72 A. Woźniak [i in.], Systemy poboru optat abonamentowych..., s. 27-28

73 Ustawa nr 1 o rozgłośniach radiowych i telewizyjnych z 1996 r. (Az 1996. évi I. törvény a rádiózásról és a televíziózásról).

74 Nowela nr XX z 2002 r., dostosowująca regulacje krajowe do Dyrektywy 89/552/EWG „Telewizja bez granic”, i z 2010 r. implementująca regulacje Dyrektywy o audiowizualnych usługach medialnych, [w:] E. Stasiak-Jazukiewicz, M. Jas-Koziarkiewicz, Polityka medialna w Unii Europejskiej, s. 489-490.

75 A. Woźniak [i in.], Systemy poboru optat abonamentowych..., s. 27-28. Zob. też: E. Stasiak-Jazukiewicz, M. Jas-Koziarkiewicz, Polityka medialna w Unii Europejskiej, s. 487-500. 
oraz dotacji budżetowych. Funduszem tym administrował do 2010 r. krajowy organ regulacyjny Komisja ds. Radiofonii i Telewizji (Országos Rádió és Televízió Testület, ORTT $)^{76}$. Ustawa z grudnia 2010 r. ustanowiła w jej miejsce nowy organ - Radę ds. Mediów (Mediatanacs).

\section{Struktura organizacyjna i model finansowania nadawców publicznych we Francji}

Strukturę działalności francuskich nadawców publicznych określają zapisy Ustawy z dnia 1 sierpnia 2000 r. o wolności komunikacji ${ }^{77}$. Sektor nadawców publicznych tworzy zdecentralizowany holding France Télévisions, będący własnością Skarbu Państwa. Zarządza on odrębnymi spółkami programowymi, będąc jednocześnie właścicielem całego kapitału tych spółek ${ }^{78}$. Są to krajowe spółki nadawcze: France 2, France 3, France 4 (od 2005 r.), La Cinquième oraz spółki wyspecjalizowane: FT Interactive, FT Publicite, FT Distribution, a także 30 mniejszych jednostek, w tym kanały tematyczne: Mezzo, Festival, Historie, będące współwłasnością France Télévisions i partnerów komercyjnych $^{79}$.

Ponadto sektor publiczny komunikacji audiowizualnej tworzą: krajowa spółka programowa emitująca programy radiowe i telewizyjne, nadawane na terytoriach zamorskich RFO (Reseau France Outre-mer) oraz spółki radiofonii Radio France i Radio France Internationale (RFI) ${ }^{80}$. Odrębną spółką nadawcy publicznego od 2000 r. jest kanał ARTE France. Były pierwszy kanał telewizji francuskiej - TF 1, został sprywatyzowany w 1986 r. decyzją ówczesnego premiera Jacques’a Chiraca.

We Francji abonament radiowo-telewizyjny nazywany jest należnością audiowizualną (redevance audiovisuelle) ${ }^{81}$. W świetle opracowania Krajowej Rady Radiofonii i Telewizji ${ }^{82}$ nazwa ta odzwierciedla istotę opłaty, gdyż obowiązek jej uiszczania przez osoby fizyczne powiązany jest z zamieszkaniem w lokalu wyposażonym w odbiornik telewizyjny lub w inne, podobne w funkcji, urządzenie odbiorcze (dosł. dispositif de réception assimilé $)^{83}$.

76 Ustawa nr 1 o rozgłośniach radiowych i telewizyjnych z 1996 r. znowelizowana 20 grudnia 2010 r. Ustawą o mediach i usługach audiowizualnych (Az 1996. évi I. törvény a rádiózásról és a televíziózásról).

77 Ustawa nr 89-25 z dnia 17 stycznia 1989 r. oraz Ustawa nr 86-1067 z dnia 30 września 1986 r. o wolności komunikacji (Loi sur le liberté de la communication), Journal Officiel de la République Française 1986; znowelizowana Ustawą nr 2000-719 z dnia 1 sierpnia 2000 r.

78 Art. 44 p. I ust. 1, 2, 3 ustawy nr 2000-719.

79 Zob. też: B. Golka, System medialny Francji, Warszawa 2001, s. 159-166; K. Gajlewicz, System medialny Francji, [w:] Wybrane zagraniczne systemy medialne, s. 129-174.

80 Art. 44 p. 2, 3, 4 Ustawy o wolności komunikacji.

81 Ustawa nr 89-25 z dnia 17 stycznia 1989 r. oraz Ustawa nr 86-1067 z dnia 30 września 1986 r. o wolności komunikacji (Loi sur le liberté de la communication), Journal Officiel de la République Française 1986; znowelizowana Ustawą nr 2000-719 z dnia 1 sierpnia 2000 r.

82 A. Woźniak [i in.], Systemy poboru optat abonamentowych..., s. 18.

83 Tamże. 
Nieistotny jest przy tym sposób wejścia w posiadanie tego odbiornika (zakup, użyczenie czy darowizna) ani to, czy dana osoba jest jego wtaścicielem, czy też nie. Osoby te optacaja jedna należność audiowizualna bez względu na liczbę odbiorników, jak też bez względu na liczbęi rodzaj posiadanych lokali (mieszkanie, dom, domek letniskowy). Istotne jest natomiast, czy dana osoba jest ptatnikiem podatku katastralnego ${ }^{84}$.

Należności tej nie płacą osoby, które w rozliczeniu rocznym podatku dochodowego zaznaczą, że nie posiadają odbiornika umożliwiającego odbiór telewizji. Należność audiowizualna wnosi się raz $w$ roku lub w ratach razem zpodatkiem katastralnym (jeden wspólny druk dla obu ptatności). Poborem obu optat zajmują się urzędy skarbowe, a podmiotem odpowiedzialnym jest Ministerstwo Gospodarki, Finansów i Przemystu ${ }^{85}$.

Osoby prawne wnosza należność audiowizualna w sposób analogiczny do rozliczania podatku VAT. Wysokość należności audiowizualnej dla osób fizycznych wynosi 116 euro (Francja metropolitarna) lub 74 euro (terytoria zamorskie). Kwotę tę, jak również szacowane wptywy z tytutu jej poboru, corocznie określa Ustawa budżetowa ${ }^{86}$. Posiadanie wyłącznie odbiornika radiowego nie rodzi obowiązku uiszczania należności audiowizualnej. W 1978 r. został zniesiony abonament za posiadanie radioodbiornika ${ }^{87}$. We Francji od wielu lat prowadzony jest rejestr osób dokonujących zakupu odbiornika telewizyjnego (jest to specjalna deklaracja, którą sklep wysyła do urzędu skarbowego). Jednocześnie fakt zaprzestania posiadania telewizora należy sformalizować poprzez wysłanie do urzędu skarbowego druku wyrejestrowującego odbiornik.

Roczne przychody z tytułu wpływów abonamentowych we Francji szacowane są średnio na ponad 2,7 mld euro, co stanowi ok. 67\% w rocznej strukturze przychodów nadawców publicznych (pozostałe dochody pochodzą z działalności komercyjnej tych instytucji $^{88}$.

Wprowadzona w 2005 r. reforma systemu abonamentowego przewidywata czasowe zwolnienie z należności audiowizualnej dla osób starszych, które korzystaty ze zwolnienia z podatku dochodowego (podwójne kryterium: wieku i najniższych dochodów). Reforma zaktadata, że zwolnienie to obowiązywać będzie wytacznie do końca $2007 \mathrm{r}$., ale tuż przed końcem tego okresu parlament francuski podjąt debatę nad ztagodzeniem przejścia do petnej odptatności należności audiowizualnej przez tę kategorię osób ${ }^{89}$. W 2008 r. przyjęto dla nich pięćdziesięcioprocentową ulgę. Kategoria ta obejmuje 800 tys. gospodarstw domowych, a petne ich zwolnienie $z$ należności audiowizualnej kosztuje rocznie budżet państwa 90 mln euro $0^{90}$.

34 E. Stasiak-Jazukiewicz, M. Jas-Koziarkiewicz, Polityka medialna w Unii Europejskiej, s. 231-249.

A. Woźniak [i in.], Systemy poboru optat abonamentowych..., s. 18; zob. też: K. Gajlewicz, System medialny Francji, s. 160. Zob.: B. Golka, System medialny Francji, s. 159-171. Zob.: Raport Commission pour la nouvelle télévision publique...; Raport Rapport Public Thématique... A. Woźniak [i in.], Systemy poboru optat abonamentowych..., s. 19. 
Do publicznych nadawców i instytucji finansowanych z należności audiowizualnej należą więc stacje telewizyjne grupy France Télévisions (France 2, France 3, La Cinquième) oraz sieć Radio France Outre-mer (RFO, tzw. sieć Francja Zamorska), kanał kulturalny Arte-France, a także Radio France (France Inter, France Info, France Culture, France Musiques, FIP, France Bleu, Le Mouv'), Radio France Internationale (RFI) oraz Krajowy Instytut Audiowizualny, zarządzający archiwami programowymi tych spółek.

Kwoty równoważne środkom z tytutu pobranej należności audiowizualnej oraz środki rekompensujące ubytki $z$ tytutu zwolnień $i$ ulg $w$ zakresie należności audiowizualnej wyptacane sa publicznym instytucjom audiowizualnym $w$ formie comiesięcznych zaliczek (1/12 przewidywanej kwoty). Natomiast kwoty wptacane przez obywateli z tytutu nalezności audiowizualnej sptywaja bezpośrednio do budżetu państwa, wyrównujac $w$ ten sposób wydatki na zaliczki dla powyższych instytucji ${ }^{91}$.

Model finansowania nadawców publicznych we Francji jest rezultatem prowadzonej przez państwo polityki medialnej. Tworzenie długoterminowej strategii finansowania mediów odbywa się z mocy porozumienia rządu i nadawców publicznych, zawieranego w trybie wzajemnych konsultacji. Główną jednostką administracji państwowej odpowiedzialną za formułowanie projektów polityki państwa w tym zakresie jest Direction du Développement des Médias (DDM). W odniesieniu do nadawców publicznych to właśnie DDM odpowiada za opracowywanie projektów dwóch podstawowych dokumentów wydawanych następnie w formie dekretów rządowych: Cahiers des charges oraz Contracts d'objectifs et de moyens ${ }^{92}$.

Pierwszy z nich, Cabiers des charges, to dokument określający zadania programowe nadawców publicznych. Drugi to dokument wprowadzony w 2000 r. w wyniku nowelizacji Ustawy o wolności komunikacji z 30 września 1989 r., który dostosowuje strategię programową do warunków i możliwości finansowania tej działalnoścị3.

Jest to więc swego rodzaju „porozumienie” między rządem a nadawcą publicznym, zawierane na okres od trzech do pięciu lat, określające z jednej strony zadania programowe i inwestycyjne wynikające z Cahier des charges, a z drugiej zawierające gwarancje finansowania działalności nadawców przez państwo, poprzez zapewnienie na ten cel odpowiednich środków w budżecie.

Zgodnie z ustawą umowy dotyczące celów i środków zawierane są pomiędzy rządem a każdą ze spółek publicznego holdingu France Télévisions, Reseau France Outre-mer (RFO), Radio France, Radio France Internationale (RFI), jak również ARTE France i Krajowym Instytutem Audiowizualnym (INAV), zarządzającym archiwami programowymi tych spółek ${ }^{94}$.

91 A. Woźniak [i in.], Systemy poboru optat abonamentowych..., s. 19.

92 A. Woźniak [i in.], Instrumenty promujące niezależność mediów publicznych na przyktadzie wybranych państw europejskich, Analiza Biura KRRiT, 2006, nr 5, s. 12.

93 Ustawa nr 89-25 z dnia 17 stycznia 1989 r. oraz Ustawa nr 86-1067 z dnia 30 września 1986 r. o wolności komunikacji (Loi sur le liberté de la communication), Journal Officiel de la République Française 1986; znowelizowana Ustawą nr 2000-719 z dnia 1 sierpnia 2000 r.

$94 \quad$ Art. 53 p. I Ustawy o wolności komunikacji. 
Umowy dotyczące celów i środków obejmują główne kierunki rozwoju spółek, z uwzględnieniem zobowiązań programowych podejmowanych z tytułu różnych inicjatyw twórczych w sektorze audiowizualnym. Zawierają kosztorysy programowe na każdy rok działalności nadawcy, prognozy na temat przewidywanych zysków z przychodów własnych spółek, w tym z reklamy i sponsoringu.

Tryb przygotowania tych dokumentów obejmuje kilka etapów konsultacji. Inicjatywa zmian w Cahier des charges bądź zawarcia nowego kontraktu z nadawcą publicznym wychodzi od jednostki administracji państwowej DDM. W konsultacjach z nadawcą określa się zakres proponowanych zmian i przedkłada do zatwierdzenia zarządowi holdingu France Télévisions, po uprzednim zaopiniowaniu projektu przez zarządy każdej ze spółek holdingu ${ }^{95}$.

Następnie projekt zmian przesyłany jest do instytucji regulacyjnej Najwyższej Rady Audiowizualnej, Conseil Superieur de L'Audiovisuel (CSA) celem wypracowania własnego stanowiska w sprawie. Rada może dokonać niezależnych ustaleń z nadawcą i przedstawić ostateczną wersję projektu do akceptacji rządu. Po zakończeniu konsultacji rząd zawiera porozumienie z nadawcą w zakresie celów i środków niezbędnych do ich realizacji. Prezes holdingu nadawców publicznych France Télévisions przedstawia każdego roku komisjom Zgromadzenia Narodowego i Senatu raport z wykonania postanowień zawartego porozumienia.

Stanowi to podstawę debaty parlamentarnej nad Ustawą budżetową, której jednym z elementów jest określenie wysokości opłaty abonamentowej. Do projektu Ustawy budżetowej załączany jest też raport rządu na temat własnej oceny wywiązania się nadawcy publicznego z powierzonych mu zadań inwestycyjnych i programowych oraz zasadności poniesionych wydatków na ich realizację.

Francuski parlament określa wysokosś abonamentu od $2004 \mathrm{r}$. W efekcie przyjęcia Ustawy budżetowej parlament zezwala na pobór opłat określanych mianem należności audiowizualnej (redevance audiovisuelle) oraz zatwierdza podział środków publicznych pomiędzy poszczególne spółki nadawców. Poborem abonamentu zajmują się służby podległe ministrowi finansów. Abonament, mimo że stanowi rodzaj daniny publicznej, nie jest indeksowany automatycznie, a od obowiązku jego płacenia uchyla się ok. 8\% abonentów ${ }^{96}$.

\section{Struktura organizacyjna działalności nadawców publicznych w Niemczech i model ich finansowania}

Niemcy są przykładem państwa o dualnym systemie medialnym, polegającym na podziale mediów ze względu na formę ich własności i sposób zarządzania. System ten zakłada istnienie obok siebie nadawców prywatnych i publiczno-prawnych, zarów-

95 A. Murawska-Najmiec, Informacja o sposobie określania zadań programowych nadawców publicznych oraz o sposobach ich finansowania i rozliczania/kontroli na podstawie wybranych przyktadów nadawców telewizyjnych, Analiza Biura KRRiT, 2004, nr 8, s. 12.

96 A. Woźniak [i in.], Instrumenty promujące niezależność mediów publicznych..., s. 18. 
no prasowych, jak i radiowo-telewizyjnych. Publiczni nadawcy radiowo-telewizyjni w Niemczech to dziesięciu landowych nadawców radiowych i telewizyjnych, którzy współpracują w ramach ARD, ZDF i Deutschlandradio ${ }^{97}$.

Związek Niemieckich Nadawców Publiczno-Prawnych ARD (Arbeitsgemeinschaft der offentlich-rechtlichen Rundfunkanstalten der Bundesrepublik Deutschland) jest jednym $\mathrm{z}$ największych publicznych nadawców radiowo-telewizyjnych w Europie, powstałym 5 sierpnia 1950 r. ${ }^{98}$ Jego założycielami było sześć rozgłośni radiowych. ARD produkuje cztery ogólnoniemieckie programy telewizyjne, w tym od 1954 r. Das Erste, będący pierwszym kanałem niemieckiej telewizji publicznej i stanowiący wspólną produkcję poszczególnych nadawców w krajach związkowych. Ponadto ARD produkuje też programy międzynarodowe, emitowane na kanale 3Sat (niemiecko-austriacko-szwajcarskim) oraz niemiecko-francuskim kanale kulturalnym ARTE. Wspólnie z drugim ogólnoniemieckim nadawcą publicznym - ZDF, ARD produkuje także kanały tematyczne: Ki.Ka (Kinder-Kanal) dla dzieci oraz kanat informacyjny Phoenix.

Obok kanałów telewizyjnych oferta nadawcy publicznego ARD to: międzynarodowy program radiowy Deutsche Welle, programy ogólnokrajowych rozgłośni Deutschlandradio (Deutschlandfunk i Deutschlandradiokultur), a także programy rozgłośni radiowych poszczególnych nadawców krajowych.

Od 1963 r. rozpoczęła nadawanie Druga Telewizja Niemiecka (Zweites Deutsches Fernsehen, ZDF), jako konkurujący z ARD drugi na niemieckim rynku telewizyjnym nadawca publiczny. W odróżnieniu od ARD, ZDF ma odmienną strukturę organizacyjną o charakterze centralistycznym. W skład czternastoosobowej rady zarządzającej wchodzą premierzy landów, przedstawiciel rządu federalnego i eksperci delegowani przez radę telewizji. ZDF ma swoje oddziały regionalne w każdym z 16 landów, a także 19 agend za granicą.

Wspólnym przedsięwzięciem ARD i ZDF jest kanał informacyjny Phoenix, nadający od 1997 r. Jego dyrektorami są przedstawiciele obydwu publicznych nadawców. Stacja relacjonuje i komentuje wydarzenia polityczne oraz transmituje obrady niemieckiego parlamentu - Bundestagu.

3Sat to telewizyjny kanał kulturalny nadający od 1984 r., powstały jako wspólny projekt telewizji publicznych trzech krajów niemieckojęzycznych: Niemiec, Austrii i Szwajcarii. Od 1994 r. partnerem 3Sat oprócz ZDF stał się nadawca publiczny ARD. Nie jest to program masowy, lecz adresowany do wąskiego grona odbiorców zaintereso-

97 K. Kamps, Politisches Kommunikationsmanagement. Grundlagen und Professionalisierung moderner Politikvermittlung, Wiesbaden 2007, s. 87-105.

98 Zob. też: B. Ociepka, System medialny Niemiec, s. 87-128; B. Ociepka, M. Ratajczak, Media i komunikowanie polityczne..., Wrocław 2004; W. Schulz, Politische Kommunikation. Theoretische Ansatze und Ergebnisse empirischer Forschung, Wiesbaden 2008; T. Moorstedt, E. Jeffersons, Wie die digitalen Medien die Politik verandern, Frankfurt am Main 2008; F. Brettschneider, Wablen in der Mediengesellschaft. Der Einfluss der Massenmedien auf die Parteipraeferenz, [w:] Perteien in der Mediendemokratie, Hrsg. U. Alemann, S. Marshal, Wiesbaden 2002; S. Fengler, B. Vestring, Politikjournalismus, Wiesbaden 2009; G. Hirscher, K.R. Korte, Information und Etscheidung. Kommunikationsmanagement der politischen Fubrung, Wiesbaden 2003. 
wanych kulturą i polityką. Antenę wypełniają głównie reportaże i filmy dokumentalne, a także transmisje koncertów i sztuk teatralnych.

ARTE (Association Relative - la Télévision Européenne) to kolejny nadawca publiczny, który rozpoczął emisję w 1992 r. Równoprawnymi dla siebie partnerami tego telewizyjnego przedsięwzięcia są ARTE France i ARTE Deutschland TV, w których równe udziały posiadają ARD i ZDF. Ten dwujęzyczny, francusko-niemiecki, kanał telewizyjny prezentuje na antenie programy kulturalne, reportaże oraz tzw. ambitne kino.

Ki.Ka, czyli Kinder-Kanal, to wyspecjalizowany kanał publiczny dla dzieci, nadający od 1997 r. Jest on wspólnym przedsięwzięciem programowym ARD i ZDF, które posiadają w nim po 50\% udziałów. Ramówka składa się nie tylko z bajek, ale też z programów informacyjnych, filmów animowanych, reportaży czy licznych programów edukacyjnych.

Deutschlandradio, zgodnie z modelem organizacji działalności mediów w Niemczech, zostało włączone do sieci ARD i ZDF w 1994 r. Oferta programowa radia publicznego w Niemczech to 57 programów radiowych nadawanych w sieci ARD. ZDF ma z kolei udziały w rozgłośniach Deutschlandfunk i Deutschlandradio Kultur, nadających program na obszarze całego kraju.

Deutschladfunk (DLF) to publiczny program pierwszy niemieckiego radia, Deutschlandradio Kultur (DLRKultur) - program kulturalno-naukowy, zaś Deutschlandradio Wissen - wyspecjalizowany zwłaszcza w publicystyce politycznej program informacyjny.

Ponadto w Niemczech nadają 22 rozgłośnie uniwersyteckie i 32 niekomercyjne stacje lokalne, które jako instytucje pożytku publicznego, działające obok nadawców publiczno-prawnych i komercyjnych, są określane mianem tzw. „trzeciego filaru”.

Dnia 1 stycznia 2013 r. wszedł w życie Międzylandowy traktat o radiofonii i telewizji (Rundfunkstaatsvertrag), zatwierdzony rok wcześniej przez niemiecki parlament ${ }^{99}$. Zgodnie z nowym prawem w Niemczech wprowadzona została jednolita miesięczna opłata abonamentowa w wysokości 17,89 euro, płacona przez każde gospodarstwo domowe lub firmę, niezależnie od liczby osób lub liczby odbiorników umożliwiających odbiór programu. Traktat został przyjęty w celu zapewnienia stabilnego finansowania mediów publicznych w sytuacji, gdy coraz większa liczba osób zobowiązanych do zgłaszania posiadanych odbiorników nie była objęta regulacją. Tym samym zrezygnowano $\mathrm{z}$ dotychczasowego obowiązku rejestracji odbiorników radiowych czy telewizyjnych ${ }^{100}$.

Nowe przepisy odzwierciedlają zmiany w sposobie korzystania z mediów. Niektórym gospodarstwom domowym i przedsiębiorstwom przysługują zwolnienia zmniejszające obciążenie finansowe poprzez wyłączenie ich z płatności lub poprzez zmniej-

99 Nowy model finansowania mediów publicznych, „Przegląd Międzynarodowy” 2013, nr 2, [online] www.krrit.gov.pl, 31 I 2013.

100 New funding regime for Public Service Broadcasting in Germany, [online] http://www.mediadem.eliamep.gr, 31 I 2013. 
szenie ich wysokości. Dotyczy to osób o niskich dochodach, korzystających z pomocy społecznej, osób niepełnosprawnych oraz organizacji charytatywnych i działających non profit. Pozostałe instytucje płacą abonament $\mathrm{w}$ zależności od liczby zatrudnionych osób. Na przykład małe (do 49 pracowników) i średnie (do 249 pracowników) firmy mają płacić odpowiednio trzykrotną i pięciokrotną wysokość składki.

Każde gospodarstwo domowe lub przedsiębiorstwo jest zobowiązane do poinformowania właściwego regionalnego nadawcy publicznego o swoim istnieniu. Ponadto nadawcy publiczni mają otrzymywać od administracji publicznej dane, które pozwolą zidentyfikować potencjalnych płatników.

Głównymi beneficjentami środków abonamentowych są przede wszystkim publiczni nadawcy regionalni, działający w sieci jako ARD oraz nadawca publiczny ZDF. W strukturze ich przychodów abonament stanowi ok. $85 \%$. Z tego tytułu ARD otrzymuje rocznie ponad 5 mld euro, a ZDF $-1,6$ mld euro ${ }^{101}$. Jedynie $6 \%$ to przychody $\mathrm{z}$ reklamy i sponsoringu. Pozostałe to zyski z koprodukcji. Udział abonamentu w strukturze przychodów nadawców publicznych należy do najwyższych w Europie.

Część środków, które trafiają do ARD i ZDF, jest następnie przekazywana innym kanałom realizującym misję publiczną. Pieniądze z abonamentu otrzymują m.in. kanał ARTE, Kinder-Kanal, Phoenix oraz 3Sat. $Z$ abonamentu finansowana jest także działalność publicznego radia (Deutschland Radio) oraz landowych rozgłośni ARD.

Poborem abonamentu zajmuje się Gebühreneinzugszentrale (GEZ) z siedzibą w Kolonii, założona w 1973 r. wspólnie przez ARD i ZDF. Instytucja ta trudni się również rozdziałem funduszy pomiędzy media publiczne, aktualizacją bazy z danymi osób płacących abonament oraz kontrolą jego przepływu. Działalność GEZ jest finansowana całkowicie $\mathrm{z}$ wpływów z opłaty abonamentowej w wysokości ok. $2 \%$.

GEZ uwzględnia w swojej bazie danych także osoby zwolnione z przyczyn społecznych z obowiązku uiszczania opłaty abonamentowej. Decyzje tego rodzaju podejmowane są przez urzędy socjalne na szczeblu miast i gmin ${ }^{102}$.

Od 2005 r. z każdej opłaty abonamentowej 1,88\% przeznaczane jest na funkcjonowanie regionalnych instytucji regulacyjnych rad radiofonii i telewizji działających w poszczególnych landach (Landesmedienanstalten). Polityka medialna jest domeną krajów związkowych, stąd też nie ma w Niemczech jednej federalnej rady radiofonii i telewizji. Każdy kraj związkowy ma własną. Funkcjonuje 14 takich ciał, gdyż regulatorzy z Berlina i Brandenburgii oraz z Hamburga i Szlezwika-Holsztynu podpisali porozumienie o powołaniu wspólnych organów ${ }^{103}$. Landesmedienanstalten najczęściej wyłaniane są przez parlamenty krajów związkowych, różnią się jednak składem. Są to $\mathrm{z}$ reguły bardzo liczne, kolegialne gremia, liczące niekiedy 40 osób, stanowiące reprezentację szerokiej części społeczeństwa danego landu.

101 H.J. Kleinsteuber, B. Thomass, Media Landcsape. Germany, [online] www.ejc.net/media_landscape/ article/germany/\#118, 31 I 2013.

102 B. Ociepka, System medialny Niemiec..., s. 104-109.

103 E. Stasiak-Jazukiewicz, M. Jas-Koziarkiewicz, Polityka medialna w Unii Europejskiej, s. 397. 
Sposób rozdziału środków abonamentowych jest określony w umowie międzylandowej ${ }^{104}$. Zasady ich podziału ustala komisja powołana przez rządy krajów związkowych (Komisja do Przeglądu i Ustalania Potrzeb Finansowych Nadawców Publicznych $\mathrm{KEF}$ ). Ustawa określa jej skład i sposób wyłaniania organów decyzyjnych. Kanclerz mianuje 16 niezależnych ekspertów, delegowanych przez kraje związkowe, powoływanych na okres pięciu lat, po jednym z każdego landu. Eksperci decydujący o podziale abonamentu, w trosce o ochronę medialnego pluralizmu, nie mogą być przedstawicielami władzy wykonawczej. Członkowie komisji nie mogą więc rekrutować się spośród pracowników administracji państwowej szczebla federalnego i krajowego ani spośród pracowników instytucji unijnych. Ponadto nie mogą być pracownikami żadnego z nadawców publicznych (chodzi o unikanie konfliktu interesów) ${ }^{105}$.

Ustawa zobowiązuje nadawców publicznych do składania komisji sprawozdania finansowego raz na dwa lata. Ocenia ona zasadność propozycji programowych i inwestycyjnych przedstawionych przez nadawców publicznych i na tej podstawie decyduje o poziomie ich finansowania $\mathrm{z}$ abonamentu ${ }^{106}$.

Do 1 stycznia 2013 r. w myśl postanowień traktatu opłata abonamentowa składała się z dwóch części: ogólnej (5,76 euro) i telewizyjnej (12,22 euro). Rozgłośnie radiowe ARD otrzymywały $93 \%$ z części opłaty ogólnej, Deutschland Radio - 7\%, stacje telewizyjne ARD otrzymywały $60 \%$ z części opłaty telewizyjnej, a ZDF - 40\%. Ponadto na finansowanie kanału kulturalnego Arte przeznaczano rocznie średnio 164 tys. euro. $\mathrm{Z}$ chwilą ujednolicenia opłaty abonamentowej od 1 stycznia 2013 r. proporcje te mogaz się zmienić.

W opinii autora omówione przykłady rozwiązań legislacyjnych w dziedzinie modelu finansowania nadawców publicznych w wybranych państwach europejskich potwierdzają tezę o konieczności zachowania systemu abonamentowego, najpełniej gwarantującego dostosowanie oferty programowej mediów publicznych do oczekiwań audytorium, wynikających z demokratycznych potrzeb każdego społeczeństwa. Jedną z nich jest choćby realizacja prawa do publicznego wyrażania krytycznych opinii na temat decyzji politycznych podejmowanych przez władze. Zdaniem autora wszyscy obywatele powinni być ustawowo zobowiązani do wnoszenia opłat za korzystanie z usług mediów publicznych. Abonament jest bowiem najlepszym gwarantem ochrony pluralizmu w mediach.

Niebezpieczne wydaje się założenie nawet częściowego finansowania mediów publicznych z budżetu państwa. Zastosowanie zasady „kto płaci, ten wymaga” w przypadku państwa mogłoby prowadzić wprost do upolitycznienia nadawcy, utarty niezależności, a w konsekwencji do spadku jego wiarygodności. Skoro media publiczne w systemie demokratycznym nie są instytucją państwa, to, zdaniem autora, nie powinny być przez państwo finansowane.

104 Traktat o finansowaniu radiofonii i telewizji z 31 sierpnia 1991 r., znowelizowany w 2008 r. (Rundfunkfinanzierungsstaatsvertrag, RFinStV vom 31.8.1991).

105 E. Stasiak-Jazukiewicz, M. Jas-Koziarkiewicz, Polityka medialna w Unii Europejskiej, s. 391.

106 Tamże, s. 381-403. 


\section{BIBLIOGRAFIA}

Adamowski J.W., Czwartystan. Media masowe wpejzażu spotecznym Wielkiej Brytanii, Warszawa 2006.

Adamowski J.W., Narodziny czwartej wtadzy. Geneza i rozwój brytyjskiego systemu medialnego (zarys problematyki), Warszawa 2005.

Adamowski J.W., System medialny Wielkiej Brytanii, [w:] Wybrane zagraniczne systemy medialne, red. J.W. Adamowski, Warszawa 2008, Edukacja Medialna.

Brettschneider F., Wablen in der Mediengesellschaft. Der Einfluss der Massenmedien auf die Parteipraeferenz, [w:] Perteien in der Mediendemokratie, Hrsg. U. Alemann, S. Marshal, Wiesbaden 2002.

Dobosz I., Prawne aspekty transformacji w mediach, [w:] Polskie media w jednoczacej się Europie. Szanse i wyzwania, red. I. Dobosz, B. Zając, Kraków 2006.

Dobosz I., Prawo prasowe, Warszawa 2011, Seria Akademicka.

Fengler S., Vestring B., Politikjournalismus, Wiesbaden 2009.

Gajlewicz K., System medialny Francji, [w:] Wybrane zagraniczne systemy medialne, red. J.W. Adamowski, Warszawa 2008, Edukacja Medialna.

Golka B., System medialny Francji, Warszawa 2001.

Hallin D., Mancini P., Systemy medialne. Trzy modele mediów i polityki w ujęciu porównawczym, przel. M. Lorek, Kraków 2007, Media.

Hirscher G., Korte K.R., Information und Etscheidung. Kommunikationsmanagement der politischen Fubrung, Wiesbaden 2003.

Jakubowicz K., Media publiczne. Początek końca czy nowy początek, Warszawa 2007, Edukacja Medialna.

Jakubowicz K., Polityka medialna a media elektroniczne, Warszawa 2008, Edukacja Medialna.

Jakubowicz K., Publiczna i prywatna telewizja, [w:] Media i dziennikarstwo w Polsce 1989-1995, red. G. Kopper, I. Rutkiewicz, K. Schliep, Kraków 1996.

Jakubowicz K., Rola i znaczenie mediów publicznych w Europie, materiały z konferencji KRRiT, Warszawa 2009, [online] http://www.krrit.gov.pl/Data/Files/_public/Portals/0/konferencje/dm_konf_080415_spraw.pdf, 31 I 2013.

Jakubowicz K., Unia Europejska a media. Między kultura a gospodarka, Warszawa 2010, Edukacja Medialna.

Jaskiernia A., Publiczne media elektroniczne w Europie, Warszawa 2006.

Kamps K., Politisches Kommunikationsmanagement. Grundlagen und Professionalisierung moderner Politikvermittlung, Wiesbaden 2007.

Kleinsteuber H.J., Thomass B., Media Landcsape. Germany, [online] www.ejc.net/media_landscape/article/germany/\#118, 31 I 2013.

Le Président de la République, Nicolas Sarkozy, a fixé des objectifspour l'audiovisuel dans une lettre adressée le ler août 2007 au ministre de la Culture et de la Communication, [online] www. francetelevisions.fr, 31 I 2013. 
Maggiore M., Rola i znaczenie mediów publicznych w Europie, materiały z konferencji KRRiT, Warszawa 2009, [online] http://www.krrit.gov.pl/Data/Files/_public/Portals/0/konferencje/dm_konf_080415_spraw.pdf, 31 I 2013.

Miżejewski M., Transformacja telewizji w Polsce po roku 1989 na tle zmian politycznych, Przemyśl 2005.

Moorstedt T., Jeffersons E., Wie die digitalen Medien die Politik verandern, Frankfurt am Main 2008.

Murawska-Najmiec A., Informacja o sposobie określania zadań programowych nadawców publicznych oraz o sposobach ich finansowania i rozliczania/kontroli na podstawie wybranych przyktadów nadawców telewizyjnych, Analiza Biura KRRiT, 2004, nr 8.

New funding regime for Public Service Broadcasting in Germany, [online] http://www.mediadem.eliamep.gr, 31 I 2013.

Nowosad A., Wtadza i media w Butgarii, Kraków 2008.

Nowy model finansowania mediów publicznych, „Przegląd Międzynarodowy” 2013, nr 2, [online] www.krrit.gov.pl, 31 I 2013.

Ociepka B., System medialny Niemiec, [w:] Wybrane zagraniczne systemy medialne, red. J.W. Adamowski, Warszawa 2008, Edukacja Medialna.

Ociepka B., Ratajczak M., Media i komunikowanie polityczne. Niemcy, Austria, Szwajcaria, Wrocław 2000.

Pasquier M., Lamizet B., Media landscape. France, [online] www.ejc.net/media_landscape/ article/france/\#118, 31 I 2013.

Prawo mediów, red. J. Barta, R. Markiewicz, A. Matlak, Warszawa 2008.

Ratajczak M., Jak porozumiewaja się Szwajcarzy? Media w wielokulturowej Szwajcarii, Wrocław 2004, Acta Universitatis Wratislaviensis, nr 2651.

Rola $i$ znaczenie mediów publicznych w Europie, materiały z konferencji KRRiT, Warszawa 2009, [online] http://www.krrit.gov.pl/Data/Files/_public/Portals/0/konferencje/dm_ konf_080415_spraw.pdf, 31 I 2013.

Schulz W., Politische Kommunikation. Theoretische Ansatze und Ergebnisse empirischer Forschung, Wiebaden 2008.

Stasiak-Jazukiewicz E., Jas-Koziarkiewicz M., Polityka medialna w Unii Europejskiej, Warszawa 2011, Europeistyka.

Stępka P., Woźniak A., Problem stosowania pomocy publicznej w kontekście dziatalności nadawców publicznych, Analiza Biura KRRiT, 2007, nr 1.

Szostok P., Środki masowego komunikowania na przyktadzie systemów medialnych Szwecji i Norwegii, [w:] Mato znane systemy medialne, red. Z. Oniszczuk, M. Gierula, Sosnowiec 2007.

The Office Of Communications Annual Report and Accounts for the Period 1 April 2010 To 31 March 2011, [online] http://www.ofcom.org.uk, 31 I 2013.

Williams K., Media w Europie, przeł. A. Piwnicka, Warszawa 2008, Edukacja Medialna. Podręcznik akademicki.

Woźniak A. [i in.], Finansowanie mediów audiowizualnych ze środków publicznych - analiza porównawcza na przyktadzie wybranych państw europejskich (aktualizacja), Analiza Biura KRRiT, 2010, nr 3. 
Woźniak A. [i in.], Instrumenty promujące niezależność mediów publicznych na przyktadzie wybranych panstw europejskich, Analiza Biura KRRiT, 2006, nr 5.

Woźniak A [i in.], Systemy poboru optat abonamentowych w wybranych państwach europejskich (aktualizacja), Analiza Biura KRRiT, 2007, nr 5

Wybrane zagraniczne systemy medialne, red. J.W. Adamowski, Warszawa 2008, Edukacja Medialna.

Dr Maciej Miżejewski - adiunkt w Zakładzie Dziennikarstwa Instytutu Nauk Politycznych i Stosunków Międzynarodowych Uniwersytetu Jagiellońskiego w Krakowie. W latach 1992-2000 dziennikarz Działu Programów Informacyjnych Telewizji Polskiej SA oddział w Krakowie. Stypendysta Universita degli Studi di Pavia we Włoszech. Autor monografii Transformacja telewizji w Polsce po roku 1989 na tle zmian politycznych (Przemyśl 2005) oraz artykułów naukowych w dziedzinie polityki medialnej, m.in. Polityczne konsekwencje nowelizacji ustawy o radiofonii i telewizji (Universitas” 2003, nr 27-28), Imperium medialne Berlusconiego (ttumaczenie z F. Giglioniego, [w:] $W$ drodze do Unii Europejskiej, red. K. Kaszuba, T. Sasińska-Klas, K. Wolny-Zmorzyński, Rzeszów 2004), Il sistema radiotelevisivo polacco sullo sfondo delle trasformazioni politiche („Nomos. Le attualita nel diritto” 2004, nr 2), Kryptoreklama a praktyka dziennikarska ([w:] Media a demokracja, red. L. Pokrzycka, W. Mich, Lublin 2007), The profession of journalist in Poland and its legal aspects („Newsletter UJ” 2008, nr 35), Polish media in a new European dimension („Newsletter UJ” 2008, nr 36). 